\title{
DESENVOLVIMENTO DO ECOTURISMO EM NOVA VIÇOSA, BA: DESAFIOS E RECOMENDAÇÕES
}

\author{
Maialú Ferreira Neves
}

Orientador: Prof. MsC. Sérgio Salazar Salvati

Monografia apresentada ao Centro de Excelência em Turismo da Universidade de Brasília como requisito parcial para a obtenção do certificado de Especialista em Ecoturismo.

Brasília, DF, Maio de 2003. 
UNIVERSIDADE DE BRASÍLIA

Centro de Excelência em Turismo

Curso de Especialização em Ecoturismo

\section{DESENVOLVIMENTO DO ECOTURISMO EM NOVA VIÇOSA, BA: DESAFIOS E RECOMENDAÇÕES}

Maialú Ferreira Neves

Banca Examinadora

Prof. MsC. Sérgio Salazar Salvati

Orientador

Brasília, DF, Maio de 2003. 
Neves, Maialú Ferreira

Desenvolvimento do Ecoturismo em Nova Viçosa, BA: Desafios e Recomendações/ Maialú Ferreira Neves.

$70 \mathrm{f}$.

Monografia (espercialização) - Universidade de Brasília. Centro de Excelência em Turismo. Brasília, 2003.

Área de concentração: Turismo

Orientador: Prof. MsC. Sérgio Salazar Salvati

1.Turismo 2. Ecoturismo. - Monografia 


\section{MAIALÚ FERREIRA NEVES}

\section{Desenvolvimento do Ecoturismo em Nova Viçosa, BA:}

Desafios e Recomendações

Comissão Avaliadora

Prof. MsC. Sérgio Salazar Salvati

Brasília, DF, Maio de 2003. 
Dedico este trabalho a toda minha família, principalmente à minha mãe e ao meu noivo Gustavo 


\section{AGRADECIMENTOS}

Agradeço primeiramente a Deus pelas oportunidades oferecidas e pela família maravilhosa que me deu. A minha mãe e amiga de todas as horas. Ao meu noivo Gustavo, por estar sempre por perto quando preciso. Ao meu irmão que apesar das brigas e discussões é uma das pessoas que mais amo no mundo. Ao meu pai por torcer pelas minhas vitórias. A minha avó paterna, Dorotéa, por me acolher em sua casa contribuindo imensamente para a realização desta pesquisa. Ao meu avô paterno, em memória, pelas histórias e pelo conhecimento e experiências que me transmitiu em nossas conversas. Obrigada a Telma por cuidar de nós, por ser tão amiga. Aos meus avós maternos, obrigada vó Haydée por me ajudar e por me ensinar sobre fé e amor ao próximo, por me ensinar suas artes e, sobretudo por seu amor e carinho. Obrigada vô Luiz por ser tudo que é, por nos ajudar sempre e sempre, você é o meu orgulho e o meu exemplo. Obrigada às segundas feiras, pelos momentos maravilhosos que me proporcionou e a todos aqueles que já participaram desses momentos de alegria. Obrigada a Bel, minha terceira avó, que cuida de mim e me deixa mais bonita, por me amar tanto. A minha sobra, meu sogro, ao Rafa, a Eloá, a Patrícia e ao Tony por serem a continuação da minha família, uma família nova e que eu amo tanto. A minha madrinha, por estar sempre presente, me ajudando, obrigada pelas conversas. A tia Mara Lúcia por estar sempre disposta a me ajudar. A tia Lídia, por ser a sua godoguinha. As minhas primas e amigas, Carol, Magui, Dá e Nem, pelas saídas, confidências e principalmente por me ajudarem tanto. A minha amiga Mariana, por sua amizade verdadeira e eterna. A tia Nadia por se tornar uma grande amiga e conselheira. Aos meus amigos da faculdade, principalmente a Camile, Dani e Daniel's por todos os trabalhos que fizemos juntos, pela amizade sincera. Aos novos amigos que eu fiz nesta pós-graduação. A todos os professores, pelo conhecimento adquirido, em especial ao prof. Sérgio meu orientador e ao prof. Wilson por ser tão amigo sempre. A Secretaria de Turismo e Meio Ambiente de Nova Viçosa, em especial a secretária Vanda Luzia que me ajudou tanto e me forneceu informações preciosas sem as quais não poderia ter realizado este trabalho. E finalmente a todos aqueles que de alguma forma contribuíram para que eu pudesse chegar até aqui. 


\section{RESUMO}

Este trabalho expõe como o turismo vem sendo desenvolvido no município de Nova Viçosa no extremo sul da Bahia, aponta os principais desafios que atividade turística está enfrentado no município, faz sugestões para que a mesma ocorra de forma mais ordenada e responsável, com vistas no desenvolvimento do ecoturismo. Enfatiza sempre que possível a importância de aumentar a integração e a participação dos atores locais no processo de desenvolvimento da atividade turística. Respeitando e envolvendo a comunidade em todo processo decisório, incentivando a diversificação da economia local, conscientizando a comunidade, o turista e o trade turístico para a importância da conservação ambiental e da responsabilidade social. 


\begin{abstract}
This work shows how tourism has being developed in Nova Viçosa in the extreme south of Bahia, Brasil. It points the main challenges that the touristic activity is facing there, and make sugestions for it happens with more responsibility, having as a goal the ecotourism development. It also emphasizes the importance of growing the integration and the participation of the local actors in all the process of tourism development. The community must be respected and envolved during all the decisions process. The tourism development have to encourage the diversification of local economy and make the community, the tourist and the touristic trade more conscious of the importance of environmental conservation and social responsibility.
\end{abstract}




\section{SUMÁRIO}

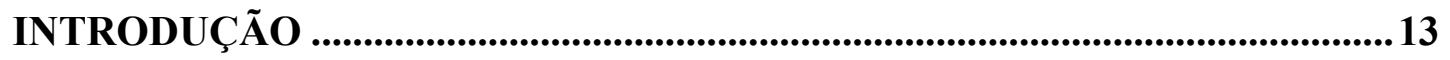

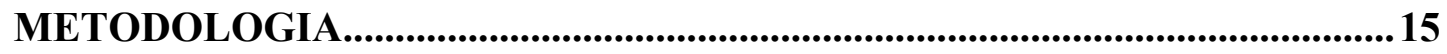

1. CARACTERIzaÇÃo da Área de eStudo E O CONTEXTO do TURISMO ...............................................................................................17

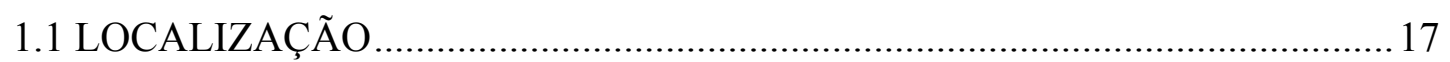

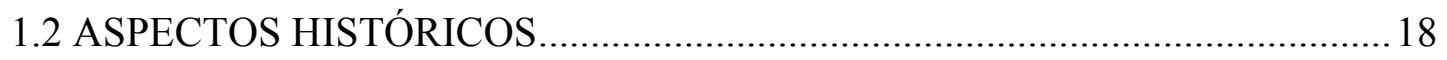

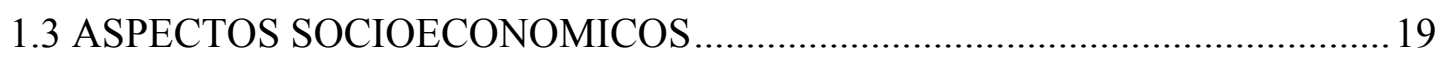

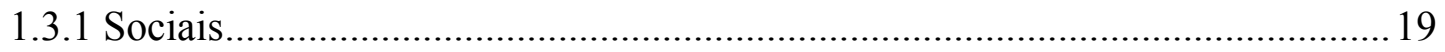

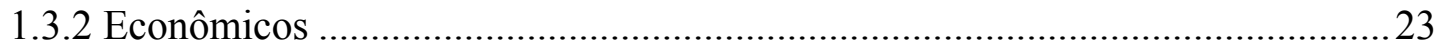

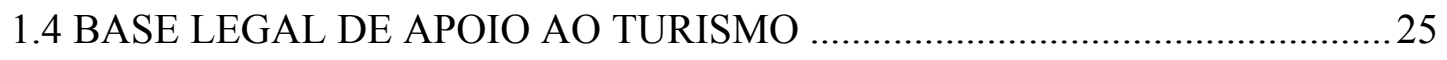

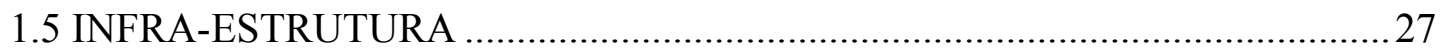

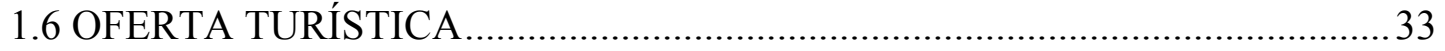

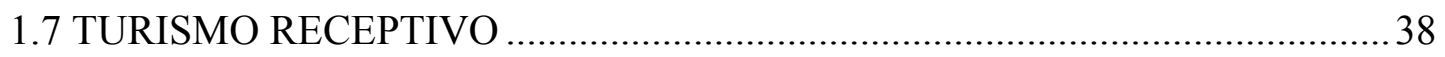

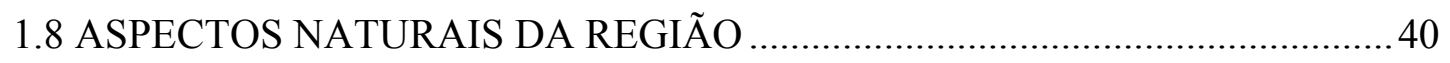

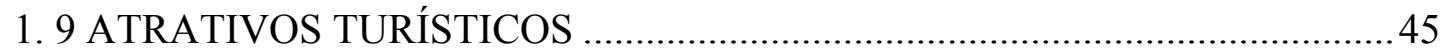

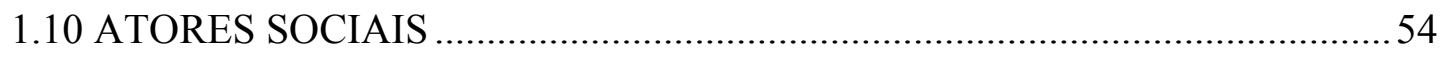

2. DESAFIOS E RECOMENDAÇÕES..........................................................60

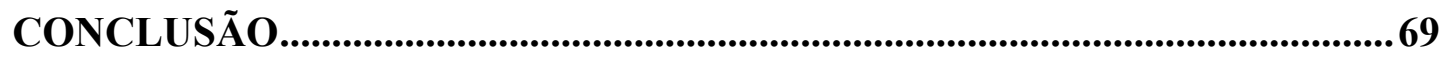

BIBLIOGRAFIA …........................................................................................................ 71 


\section{LISTAS DE ILUSTRAÇÕES}

\section{TABELAS E MAPAS}

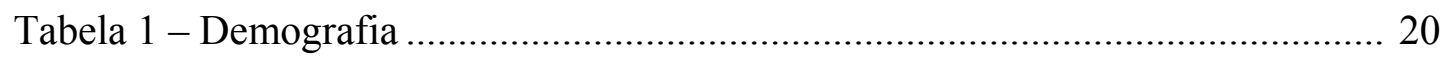

Mapa 1 - Áreas limítrofes da cidade de Nova Viçosa no extremo sul da Bahia ....... 17

\section{FIGURAS}

Figura 1 - Foto aérea de Nova Viçosa ................................................................ 44

Figura 2 - Foto aérea das praias de Nova Viçosa................................................... 45

Figura 3 - Foto aérea encontro do Rio Peruípe com o Oceano ...............................46

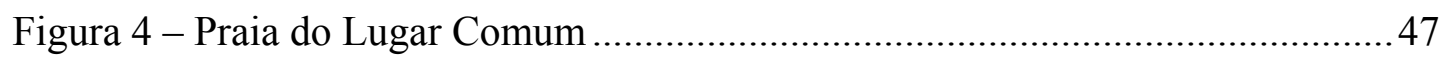

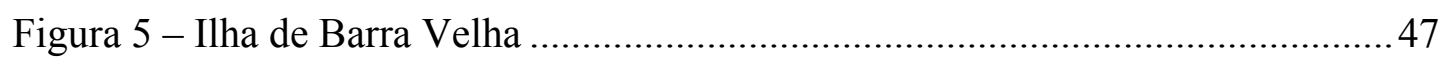

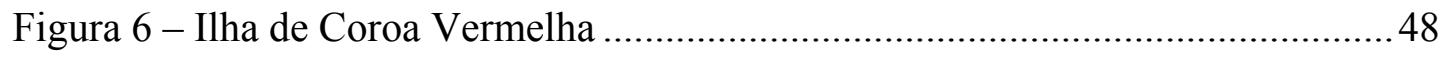

Figura 7 - Parque Nacional Marinho de Abrolhos................................................... 49

Figura 8 - Coral Mussismulia brasiliensis (O Cérebro) ..............................................50

Figura 9 - Matriz de Nossa Senhora da Conceição...................................................52

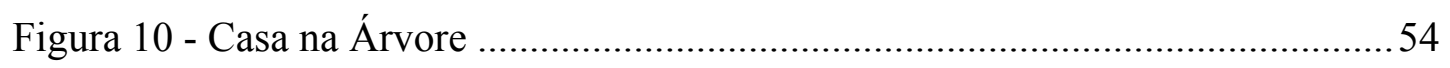




\section{LISTA DE ABREVIATURAS}

ABAV - Associação Brasileira das Agências de Viagens

APA - Área de Proteção Ambiental

ASCANOVI - Associação dos Cabaneiros de Nova Viçosa

ASHONOVI - Associação dos Hotéis, Pousadas, Campings, Condomínios de Nova Viçosa

Bahiatursa - Empresa de Turismo da Bahia

BANCOB - Banco Cooperativo do Brasil

BANEB - Banco do Estado da Bahia

BB - Banco do Brasil

CAR - Companhia de Desenvolvimento e Ação Regional

COELBA - Companhia de Eletricidade do Estado da Bahia

CRA - Centro de Recursos Ambientais da Bahia

DETRAN - Departamento de Trânsito

EMBASA - Empresa Baiana de Águas e Saneamento

EMBRATUR - Instituto Brasileiro de Turismo

FGV - Fundação GetúlioVargas

IBAMA - Instituto Brasileiro de Meio Ambiente e dos Recursos Naturais Renováveis

IBGE - Instituto Brasileiro de Geografia e Estatística

IDS - Índice de Desenvolvimento Social

MESOJEQUIMUCURI - Mesoregião do Jequitinhonha - Mucuri

OMT - Organização Mundial do Turismo

ONG - Organização Não Governamental

PCN - Parâmetros Curriculares Nacional

PESCANOVA - Associação de Pesca Aqüicultura Noviçosence

PIB - Produto Interno Bruto

PNMT - Programa Nacional de Municipalização do Turismo

PRODETUR NE - Programa de Desenvolvimento do Turismo do Nordeste

PROFA - Programa de Formação de Professores Alfabetizadores

PSF - Programa de Saúde da Família 
RAIS - Relação Anual de Informações Sociais

RIMA - Relatório de Impacto Ambiental

RPPN - Reserva Particular do Patrimônio Natural

SEBRAE - Serviço Brasileiro de Apoio às Micro e Pe quenas Empresas

SEI - Superintendência de Estudos Econômicos e Sociais da Bahia

SEPLANTEC - Secretaria de Planejamento, Ciência e Tecnologia

SUS - Sistema Único de Saúde 


\section{INTRODUÇÃO}

Segundo o Instituto Brasileiro de Turismo ${ }^{1}$ (EMBRATUR), ecoturismo é um segmento da atividade turística que utiliza de forma sustentável o patrimônio natural e cultural, incentiva sua conservação e busca a formação de uma consciência ambientalista através da interpretação do ambiente, promovendo o bem estar das populações envolvidas.

Para que uma atividade turística seja considerada ecoturismo, esta tem que respeitar a comunidade local. A comunidade deve participar de todo processo decisório do desenvolvimento do ecoturismo, que deve trazer benefícios econômicos, sociais e ambientais para o local. Além disso, a atividade ecoturística também deve primar pela interpretação do ambiente visitado e pela educação ambiental dos turistas e da comunidade receptora.

O ecoturismo é a atividade turística que mais vem crescendo nos últimos anos, tanto no Brasil como a nível mundial. Segundo a Organização Mundial do Turismo (OMT), enquanto o turismo mundial cresce 7,5\% ao ano, o ecoturismo cresce mais de $20 \%$. Estima-se que mais de meio milhão de pessoas no Brasil pratiquem o ecoturismo.

O Estado da Bahia não tem sido diferente, tendo alguns municípios já bastante conhecidos pelo desenvolvimento do ecoturismo, como Lençóis na Chapada Diamantina e Itacaré na Costa do Cacau. Nova Viçosa, que se localiza na Costa das Baleias, é uma região privilegiada, formada por algumas áreas remanescentes de mata atlântica, restinga, manguezal, alagados, ilhas oceânicas e recursos hídricos. A cidade é também ponto de partida para o Parque Nacional Marinho de Abrolhos.

Nova Viçosa possui também um calendário de festas culturais, onde se destaca a festa da Baleia Jubarte, que acontece na última semana de julho. Além disso, possui um centro histórico datado do século XVIII, e o seu distrito, Helvécia, tem população descendente de negros escravos, possuindo história e cultura muito ricas.

\footnotetext{
${ }^{1}$ www.embratur.gov.br/temas, em 23 de maio de 2003.
} 
Apesar do grande potencial para desenvolver o ecoturismo, atualmente Nova Viçosa está desenvolvendo o chamado "turismo de praia" e enfrentando problemas trazidos pela sazonalidade acentuada e pelo turismo de massa. Os atrativos oferecidos ao público, com exceção de Abrolhos, não têm qualquer tipo de trabalho de interpretação. Para os atrativos histórico-culturais não há sequer um passeio programado. Faltam aos passeios o principal, que é agregar valor a aquilo que se está visitando.

O fluxo turístico da cidade vem crescendo, assim como os serviços turísticos oferecidos. O turismo pode contribuir enormemente para o desenvolvimento econômico de um município, mas tem de vir de forma responsável, trazendo benefícios para a comunidade, e tentando minimizar os impactos negativos que este pode trazer se for desenvolvido de forma desordenada.

O ecoturismo, por ser uma atividade de menor impacto ambiental, é ideal para Nova Viçosa, que possui áreas naturais belas, porém bastante frágeis como o manguezal e os remanescentes de mata atlântica, por exemplo. Sendo assim, este trabalho visa dar um panorama geral sobre como o turismo vem se desenvolvendo em Nova Viçosa. Mostrando os principais desafios encontrados hoje e sugerindo novos rumos para o turismo local. 


\section{METODOLOGIA}

Este trabalho partiu de uma monografia já existente sobre Nova Viçosa intitulada "Análise da Atividade Turística de Nova Viçosa - BA e Sugestões para um Desenvolvimento Turístico Sustentável" feito pela mesma autora em 2000 para obtenção do título de graduação em Turismo. Assim sendo, os dados pré-existentes foram atualizados e trabalhados através de pesquisas secundárias e primárias.

O trabalho consistiu em 2 etapas. Primeiramente, em Brasília, onde foi feita uma pesquisa em fontes de dados secundários como internet e em publicações disponíveis sobre o município de Nova Viçosa e a região do extremo-sul da Bahia. E uma segunda etapa, feita in loco, onde foram observados de forma empírica o funcionamento do sistema turístico, serviços e equipamentos, alguns atrativos turísticos e sua conservação. Foram feitas também, coletas de dados junto às Secretarias Municipais, principalmente a Secretaria de Turismo onde foram levantados dados secundários de extrema importância como diagnósticos turísticos feitos anteriormente, pesquisas da demanda realizadas pela Bahiatursa, dentre outros.

Outra etapa importante foi a de coleta de dados primários através de entrevistas e questionários feitos com alguns atores do turismo local. As entrevistas tiveram o objetivo não só de colher dados sobre a situação atual do turismo na cidade, mas de saber os projetos em andamento e futuros, bem como perceber a visão que os atores entrevistados têm do turismo e sua integração em prol do desenvolvimento do mesmo.

Alguns dos atores locais entrevistados foram: Sr. Ronaldo, enfermeiro no Posto de Saúde da cidade de Nova Viçosa; a Sra. Vanda Luzia, secretária de turismo municipal; a Sra. Lucenilde, presidente da Associação dos Hotéis, Pousadas, Campings, Condomínios de Nova

Viçosa (ASHONOVI); Sr, Gustavo, empreendedor turístico; Sr. Samuel, Presidente da Associação dos Artesãos; dentre outros. 
Os questionários utilizados foram retirados do Manual de Ecoturismo de Base Comunitária do WWF - Brasil. É importante salientar que o número de questionários aplicado não dá uma amostra significativa, pois não houve tempo, nem recursos humanos (a autora trabalhou sozinha) suficientes para isso. 


\section{CARACTERIZAÇÃo da ÁREA de ESTUdo E O CONTEXTO DO TURISMO}

\subsection{LOCALIZAÇÃO}

O município de Nova Viçosa localiza-se no extremo sul da Bahia e faz parte da chamada Costa das Baleias. Sua área total é de $1330 \mathrm{~km}^{2}$, e o mesmo encontra-se a 989

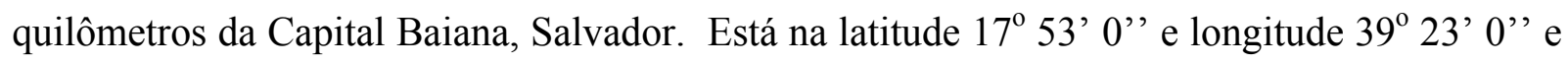
a uma altitude de $4 \mathrm{~m}$. Seus municípios limítrofes são: ao norte Caravelas, ao sul Mucuri, à leste o Oceano Atlântico e à oeste Ibirapoã. São Distritos de Nova Viçosa: Posto da Mata, Helvécia, Argolo, Colônia Nova, Bela Vista, Marobá e Cândido Mariano.

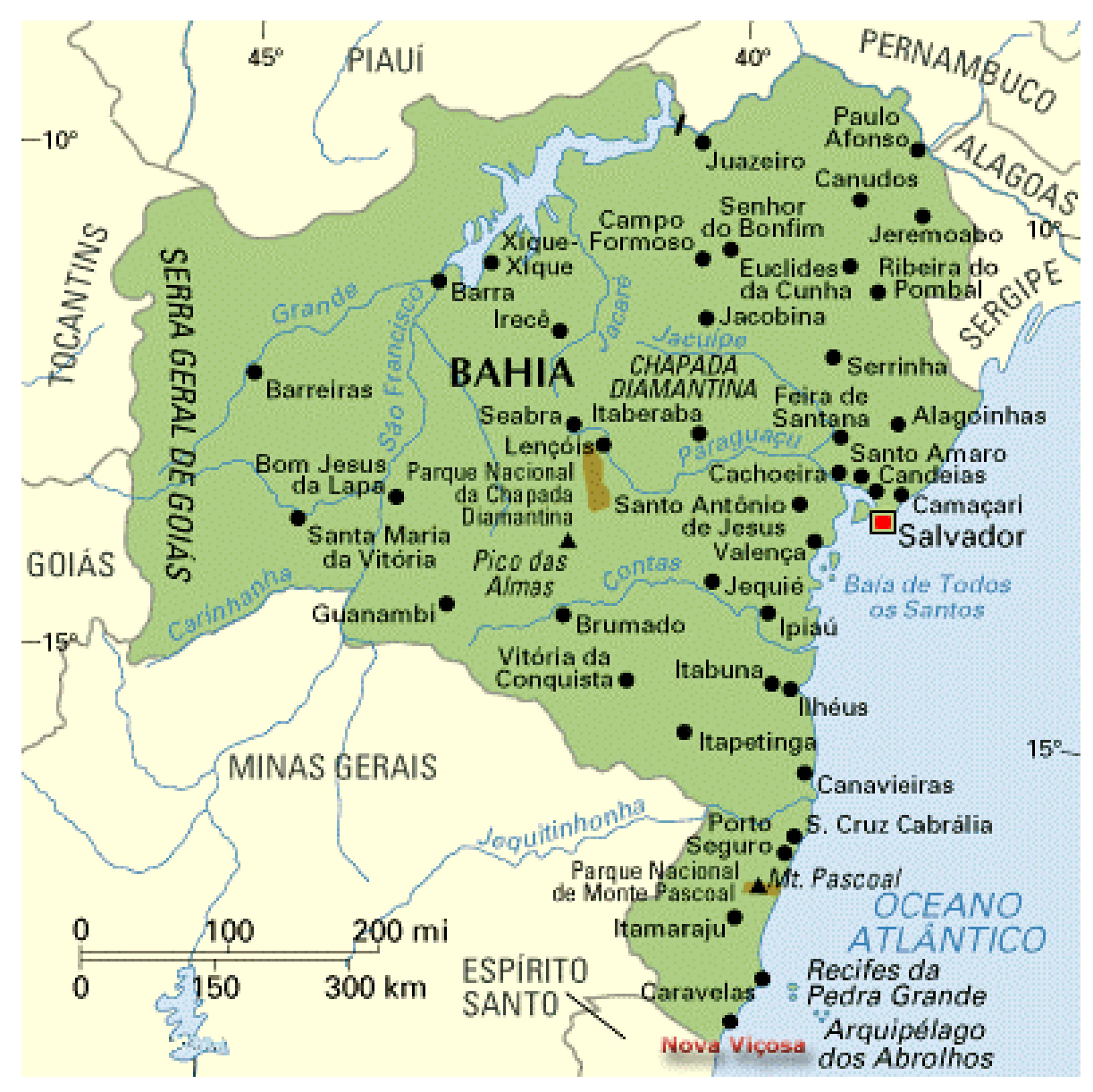

Mapa 01 - Áreas limítrofes da cidade de Nova Viçosa no extremo sul da Bahia 
A localização de um município turístico é de extrema importância para o marketing, pois normalmente é mais fácil conquistar o público das cidades e estados mais próximos ao município. No caso de Nova Viçosa, existem três estados que podem ser mais bem trabalhados: a própria Bahia, Minas Gerais e o Espírito Santo. Uma maior divulgação nas cidades próximas ao município ajuda a diminuir a sazonalidade, problema constante no turismo.

As principais capitais brasileiras também devem ter atenção especial por serem pólos emissores e portão de entrada do turismo internacional. Cidades como Rio de Janeiro, São Paulo, Belo Horizonte, Brasília (que já é um pólo emissor significativo para Nova Viçosa), Vitória e Salvador devem ser prioritárias nas campanhas de marketing voltadas para o ecoturismo. Além disso, Nova Viçosa pode ser vendida como destino complementar de cidades turísticas já consagradas, como Porto Seguro, Ilhéus, Itacaré, dentre outras.

\subsection{ASPECTOS HISTÓRICOS}

A história do município de Nova Viçosa começou às margens do rio Peruípe (que em tupi-guarani significa "Rio dos Tubarões") com a fundação do Arraial de Campinho do Peruípe, pelo capitão João Domingos Monteiro. O município foi criado, com território desmembrado de Caravelas, com sede na aldeia indígena de Campinhos, denominada por Vila Viçosa, por força de Carta Régia de 03.03.1755.

Após a vitória da revolução de 1930 por influência política do intendente de Mucuri, conseguiu-se em 1931, que fosse feita por decreto, a anexação do município de Vila Viçosa ao de Mucuri, assinado pelo Interventor Federal do Estado Dr. Leopoldo Afrânio Bastos do Amaral. Em 1943 como distrito de Mucuri, teve o topônimo alterado para Marabá. Nesse período Viçosa perdeu inúmeros documentos históricos, além de imagens e objetos sacros da Matriz de Nossa Senhora da Conceição. 
Em 27.07.1962 Viçosa readquiriu sua autonomia administrativa, por Lei Estadual, passando o município a ser denominado Nova Viçosa, com os territórios integrais dos distritos de Nova Viçosa e Helvécia e parte dos territórios de Argolo e Mucuri (desmembrados de Mucuri) e do território de Ponta de Areia (desmembrado de Caravelas).

Apesar de ser uma cidade antiga, com uma população descendente de índios e negros quilombolas, Nova Viçosa não tem aproveitado bem este potencial turístico, poucos são os turistas que visitam os prédios históricos, mesmo porque não há um produto formatado nesse sentido.

\subsection{ASPECTOS SOCIOECONÔMICOS}

O inventário dos principais aspectos socioeconômicos do município é de fundamental importância para a compreensão do turismo. O desenvolvimento do turismo em uma região sempre influencia direta ou indiretamente os outros setores da economia, bem como na oferta da infra-estrutura e dos serviços básicos municipais, além de gerar empregos. Um dos objetivos principais ao se desenvolver o turismo em um local é melhorar a qualidade de vida de seus moradores e, conseqüentemente oferecer uma melhor estrutura para o turista.

\subsubsection{Sociais}

O turismo influencia diretamente em vários aspectos sociais de um município e necessita deles para se desenvolver de forma mais responsável, visando a sustentabilidade local. A demografia é um desses aspectos. Dados demográficos podem ser utilizados no planejamento estratégico do turismo visando saber, por exemplo, quanto da população está em idade economicamente ativa, para se ter uma noção da disponibilidade de mão-de-obra local.

No caso de Nova Viçosa, segundo dados do Instituto Brasileiro de Geografia e Estatística (IBGE) no Censo 2000, a população total é de 32.076, sendo a maior parte de jovens, somando 15.483 habitantes de 0 a 19 anos. O número de pessoas residentes com idade entre 20 e 59 anos soma 14.305 , tendo apenas 2.288 habitantes com 60 anos ou mais. Isso 
mostra que há um número relativamente bom de pessoas economicamente ativas e que, num futuro próximo também haverá mão-de-obra disponível, o que é interessante para os investidores.

Ao observarmos a tabela a seguir, verificamos uma mudança no perfil da população municipal entre os dois Censos realizados. Em 1996 a população municipal era mais rural e em 2000 é mais urbana. Vale destacar que o êxodo rural apresentado entre os dois Censos é bastante significativo, pois a população rural teve uma queda de mais de $50 \%$ de sua população, enquanto que a população urbana dobrou.

O turismo se bem planejado, pode ajudar a conter e até mesmo reverter o êxodo rural, uma vez que este necessita diretamente dos produtos do campo para o abastecimento de pousadas, restaurantes, etc. Além de poder desenvolver também o turismo rural como forma de diversificar a economia no campo. Quanto às populações masculinas e femininas observase que continuam equilibradas.

Tabela 1 - Demografia

\begin{tabular}{|c|c|c|c|c|c|c|}
\hline \multirow{2}{*}{ Período } & \multicolumn{2}{|c|}{ População Urbana } & \multicolumn{2}{|c|}{ População Rural } & \multirow{2}{*}{$\begin{array}{c}\text { População } \\
\text { Total }\end{array}$} & \multirow{2}{*}{$\begin{array}{c}\text { Densidade } \\
\text { Demográfica } \\
\left(\mathbf{h a b} / \mathbf{k m}^{2}\right)\end{array}$} \\
\hline & Homem & Mulher & Homem & Mulher & & \\
\hline 1996 & 5088 & 5048 & 8725 & 8462 & 27.323 & 20,54 \\
\hline 2000 & 12.380 & 12.256 & 3.892 & 3.548 & 32.076 & 24,11 \\
\hline
\end{tabular}

Fonte: IBGE Censos Demográficos 1996 e 2000

O nível de trabalhadores empregados é outro fator que deve ser considerado, pois o turismo costuma aumentar a geração de empregos diretos e indiretos. No caso de Nova Viçosa e de todos os municípios que fazem parte da Costa das Baleias (Prado, Alcobaça, Caravelas, Nova Viçosa e Mucuri), região turística em que está inserida, o turismo ainda sofre forte influencia da sazonalidade, o que torna o número de trabalhadores temporários considerável. 
De acordo com dados da Relação Anual de Informações Sociais (RAIS) ${ }^{2}$, em 2000, o total de empregados no município de Nova Viçosa era de 3.242, um índice habitante/emprego de 1,7 o mais baixo da Costa das Baleias. Porém deve-se levar em consideração que estas informações da RAIS são relativas a empregos registrados em carteira profissional, e no Brasil de uma forma geral existem muitos trabalhadores informais.

Outro dado que deve ser observado, é o Índice de Desenvolvimento Social (IDS) do município, onde são levados em conta os níveis de saúde, educação, serviços básicos e a renda média da população local. Este índice é importante para comparar o município com os outros municípios do estado e também para saber se um dos principais objetivos do turismo está se cumprindo, que é a melhoria da qualidade de vida da população local.

Segundo dados da Superintendência de Estudos Econômicos e Sociais da Bahia (SEI), o IDS de Nova Viçosa foi em 1996, $96^{\circ}$ no ranking do estado. Já em 2000, este índice teve um aumento expressivo passando para $38^{\circ}$ no ranking estadual, perdendo somente para Mucuri na Costa das Baleias, que ocupa a $29^{\mathrm{a}}$ posição (total de 415 municípios).

\section{A Educação e o Turismo}

O turismo e a educação têm sempre que trabalhar juntos, afinal os empresários necessitam de mão-de-obra qualificada. No setor de serviços, e mais especificamente no turismo, o contato entre o turista e o prestador de serviços é freqüente, itens como fluência verbal e cultura geral são de grande importância.

Segundo dados do IBGE, em 2000, o município de Nova Viçosa contava com 14 estabelecimentos de ensino pré-escolar, 37 estabelecimentos de ensino fundamental e 3 estabelecimentos de ensino médio. Sendo a taxa de alfabetização para residentes com 10 anos ou mais, apenas de $74,9 \%$, podendo e devendo ser melhorada.

\footnotetext{
${ }^{2}$ RAIS - Relação Anual de Informações Sociais - Ministério do Emprego e Trabalho
} 
O município não possui estabelecimento de ensino superior. Normalmente os alunos fazem o ensino superior em cidades próximas como, por exemplo, Teixeira de Freitas. A cidade de Nova Viçosa possui um centro de treinamento de professores, com auditório, quadras poliesportivas e uma pequena biblioteca.

O município tem demonstrado preocupação com a melhoria da qualificação de seus professores e participa de alguns programas nesse sentido, são eles: o Programa de Formação de Professores Alfabetizadores (PROFA), o Parâmetros Curriculares Nacional (PCN), o FLUXO que é um programa para regularização idade-série. Antes do começo de cada ano letivo acontece um Fórum Municipal de Educação, onde são feitas oficinas e palestras.

Os alunos do ensino fundamental têm aulas de educação ambiental e, no ensino médio são dadas matérias de turismo e de relações humanas. Todas essas matérias são importantes para que a população local saiba respeitar e conservar o meio ambiente, se relacionar melhor com o turista, bem como compreender mais o fenômeno turístico e suas conseqüências. Outros temas como drogas e sexualidade são abordados na matéria de ciências.

\section{Saúde}

O turismo depende diretamente dos serviços de saúde local, e dependendo do tipo de turismo que é desenvolvido, como o turismo de aventura, por exemplo, (não é o caso de Nova Viçosa), este item se torna vital. O município possui 04 unidades ambulatoriais, 01 centro de saúde e 03 postos de saúde, mas apenas um é na sede de Nova Viçosa. Neste posto são prestados serviços básicos, ambulatoriais e de emergência, estando aberto 24 horas.

O único hospital do município é no distrito de Posto da Mata (relativamente distante da cidade de Nova Viçosa e particular), e que segundo dados do IBGE, é conveniado ao Sistema Único de Saúde (SUS) e possuía 46 leitos em 2000. O município vizinho (Mucuri) que dista $31 \mathrm{~km}$ da cidade de Nova Viçosa possui um hospital (particular), os casos mais graves são atendidos em um outro município vizinho, Itabatã, em hospital também particular. A falta de 
um hospital na cidade de Nova Viçosa pode fazer com que alguns turistas, principalmente estrangeiros e idosos não queiram visitar a cidade.

A cidade possui uma ambulância, um carro do Programa de Saúde da Família (PSF), e os seguintes servidores na área de saúde na cidade de Nova Viçosa, segundo dados colhidos in loco, em fevereiro de 2003 com o senhor Ronaldo, enfermeiro do posto de saúde local: 12 agentes comunitários de saúde; 3 atendentes de enfermagem; 7 auxiliares de enfermagem, 1 enfermeiro, 1 técnica, 2 dentistas; 6 médicos.

Os principais programas na área de saúde são os de prevenção e tratamento da tuberculose, hanseníase, diabetes, hipertensão, imunização, além de programas de saúde da mulher e de planejamento familiar. A sede de Nova Viçosa possui ainda 03 farmácias, sendo uma delas municipal. Apesar de ter melhorado muito nos últimos anos a área de saúde na cidade de Nova Viçosa, segundo entrevistas feitas alguns moradores em fevereiro de 2003, ainda deixa a desejar. Para o turismo e para os próprios moradores é importante que se tenha um hospital público, com equipamentos adequados.

\subsubsection{Econômicos}

A avaliação de dados econômicos do município é fundamental para a compreensão do papel que o turismo tem na economia municipal e para situar a economia municipal no contexto estadual e da Costa das Baleias. De acordo com dados da SEI, em 1997, Nova Viçosa apresentava um Produto Municipal da ordem de R $\$ 117.797,09$, colocando-se em $36^{\circ}$ no ranking baiano. Já em 1998, o Produto Interno Bruto (PIB) municipal passou para $\mathrm{R} \$ 72.317,23$, caindo para $53^{\circ}$ posição no ranking baiano. É importante salientar que esta queda não ocorreu somente com Nova Viçosa, mas com quase todos municípios da Costa das Baleias, com exceção de Mucuri que passou da $16^{\mathrm{a}}$ para a $6^{\mathrm{a}}$ posição no ranking baiano.

Essa diferença de Mucuri para os outros municípios da Costa das Baleias se dá, segundo a Síntese do Diagnóstico da Costa das Baleias realizada pela Fundação GetúlioVargas (FGV) /HVS International para o Programa de Desenvolvimento do Turismo do Nordeste 
(PRODETUR NE - II) ${ }^{3}$, pela instalação da Bahia Sul (empresa de papel e celulose) em Mucuri, o que faz com que o PIB de Mucuri chegue a ser quase nove vezes maior que dos demais municípios, apesar de ter uma população muito parecida.

Ainda segundo o mesmo trabalho ${ }^{4}$, no contexto da Costa das Baleias, "os poucos empreendimentos industriais existentes são importantes para a economia de toda a região. As atividades agropecuárias, passando por uma definição a respeito de seu potencial e os principais produtos, também ocupam papel de destaque. (...) A fragilidade dessa última e a importância de desconcentração das receitas da área de papel e celulose, sugere que o turismo pode ser desenvolvido como atividade inicialmente complementar e, após contínuo aprimoramento, desempenhar papel de destaque na arrecadação de impostos e geração de emprego e renda".

No município de Nova Viçosa, no Setor Primário, a agricultura é bem diversificada tendo plantio de feijão, abóbora, melancia, cacau, cana-de-açúcar, dentre outros, sendo que as principais culturas permanentes são a cana-de-açúcar, o mamão (principal), a mandioca e o coco-da-bahia. Na pecuária, o município tem criações de bovino, eqüino, muar, asinino, suíno, galinhas, dentre outros. A silvicultura é bastante desenvolvida na região, onde há grandes plantações de eucalipto que abastecem principalmente a Aracruz Produtos de Madeira e a Bahia Sul Celulose. Na atividade pesqueira merece destaque a pesca do camarão. Muitas famílias ainda vivem da pesca em Nova Viçosa, que já possui alguns frigoríficos.

No Setor Secundário, o destaque é para a produção madeireira (eucalipto) com a implantação em março de 1999, no distrito de Posto da Mata, da Aracruz Produtos de Madeira S.A., este empreendimento produz madeira tratada direcionada para as indústrias de móveis e revestimentos. Além disso, destacam-se também as indústrias alimentícias, de compensado, da construção (que intensificou-se com o desenvolvimento do turismo).

\footnotetext{
${ }^{3}$ PRODETUR NE-II Síntese do Diagnóstico - Costa das Baleias - reunião de Nova Viçosa. Fundação Getúlio Vargas/HVS Intenational - São Paulo - Outubro de 2002. Pág. 2.

${ }^{4}$ Idem. Pág. 4 e 5
} 
No Setor Terciário, se destacam o comércio e o turismo que tem crescido muito nos últimos anos. Porém, no contexto geral, o turismo ainda não é a principal atividade econômica. Este fato se deve principalmente, a forte sazonalidade que ainda existe na região. O turismo poderá contribuir muito na região, mas para isso é preciso que se desenvolva de forma responsável e integrada com os outros setores da economia, beneficiando e expandindo as atividades econômicas já existentes, principalmente a agricultura, a pesca, o artesanato e o comércio. Contribuirá também para que o município conserve os recursos naturais e culturais da região. Na cidade de Nova Viçosa dentre todos os setores a pesca é atualmente a atividade que mais se destaca.

Ainda segundo a Síntese do Diagnóstico da Costa das Baleias realizada pela FGV/HVS International para o PRODETUR NE - $\mathrm{II}^{5}$, a Costa das Baleias de forma geral e mais especificamente Nova Viçosa depende muito das receitas provindas de transferências correntes do Governo Estadual e da União, chegando em média a totalizar mais de $80 \%$ das receitas totais dos municípios.

\subsection{BASE LEGAL DE APOIO AO TURISMO}

Para que o turismo se desenvolva de forma ordenada e responsável, algumas ferramentas de gestão se tornam imprescindíveis. As mais importantes são Plano Diretor, Leis de uso e ocupação do solo, leis ambientais, Código de obras e de postura, Planta de Valores Imobiliários e os Conselhos de turismo e meio ambiente. Outras ferramentas importantes são Política Pública Municipal para o Turismo, Plano Setorial de Turismo e Meio Ambiente, dentre outros.

No caso de Nova Viçosa, o município possui apenas Lei Orgânica - Lei nº 309/89, de 30/11/89, Plano de Valores Imobiliários (1997), Código de Obras, Código de Posturas, sendo aplicáveis as leis Federais e Estaduais quando necessário. Possui também um Conselho Municipal de Turismo. O Conselho Municipal de Turismo não tem tido grande atuação. Segundo entrevista realizada com a secretária de turismo Vanda Luzia o Conselho se reúne

\footnotetext{
${ }^{5}$ Idem. Pág 16 a 18
} 
cinco vezes ao ano, tendo conselheiros tanto do governo municipal como dos empresários e da sociedade civil organizada.

No entanto ao entrevistar a presidente da Associação dos Hotéis, Pousadas, Campings e Condomínios, Lucenildes Fernandes, esta relatou que no ano passado havia tido somente uma reunião. Talvez essa postura mude um pouco, pois em setembro do ano passado, foi criado um grupo gestor chamado provisoriamente de Pró-turismo formado por alguns empresários locais.

Ainda não existe Plano Diretor. No entanto, este já foi elaborado em conjunto com a comunidade, já passou por análise da Companhia de Desenvolvimento e Ação Regional (CAR)/ Secretaria de Planejamento, Ciência e Tecnologia (SEPLANTEC) e agora só está faltando levado-lo a Câmara de Vereadores para votação e aprovação. Este é um Plano Diretor Urbano e a prefeitura já foi avisada que no futuro terá que complementa-lo, pois agora os municípios terão que ter um Plano Diretor para todo município.

Apesar de não ser um plano diretor municipal, este plano já irá ajudar muito, pois poderá controlar mais o crescimento da atividade turística. Para isso este tem que ser bem implementado e fiscalizado. O Plano Diretor é uma das formas de se garantir que as características e os recursos locais serão mantidos no futuro, e a atividade turística depende disso para sua sobrevivência. Sem isso, o que atrai o turista se perde. No entanto é importante que se diga que o plano diretor urbano deve ser complementado o mais rápido possível, pois, a maior parte dos atrativos naturais e culturais que interessam ao desenvolvimento do ecoturismo na região está em área rural e precisa ser ordenado e protegido.

O município não possui Leis Municipais de uso do solo, assim sendo, são utilizadas as Leis Estaduais e Federais. A história da ocupação do solo de Nova Viçosa começou com a colonização, houve uma substituição gradual e lenta da vegetação nativa, a Mata Atlântica, pelas cidades e pelo desenvolvimento da agricultura na região. Depois com a criação da BR101, que facilitou o acesso e a comunicação do município com as outras cidades do país, 
houve um avanço da pecuária e mais recentemente da silvicultura (plantio do eucalipto) que abastece as indústrias locais.

O município possui vários ecossistemas considerados frágeis, aos quais incluem-se o manguezal, brejos e áreas de restingas, todos associados à Mata Atlântica. Nova Viçosa possui um Parque Ecológico Municipal e parte do município está dentro de uma Área de Proteção Ambiental Estadual (APA) chamada Ponta da Baleia - Abrolhos. Dessa APA fazem parte também os municípios vizinhos de Caravelas e Alcobaça. A APA por enquanto só existe no papel visto que ainda não foram feitos estudos essenciais como o Estudo de Capacidade de Carga e o plano de manejo.

\subsection{INFRA-ESTRUTURA}

A infra-estrutura local é o que dá base para o desenvolvimento do turismo em uma região. Se a infra-estrutura local não acompanhar a oferta turística vários problemas aparecerão e comprometerão a qualidade da experiência turística e até mesmo o futuro da atividade turística na região. Nesse sentido a integração entre os atores pode ajudar muito, pois em uma gestão participativa a própria comunidade e os empresários podem decidir aonde devem ser feitas as melhorias e o que é prioritário e, assim, melhorar a qualidade de vida local.

\section{Acesso}

A Cidade de Nova Viçosa fica a $989 \mathrm{~km}$ de Salvador. O acesso ao município é um dos principais fatores para o desenvolvimento econômico e turístico de uma região. Em Nova Viçosa não foi diferente. Com a construção da estrada que liga Mucuri a Nova Viçosa, a BA 698, o fluxo de visitantes aumentou bastante. O acesso à cidade hoje, de carro se dá pela BR 101 e de Mucuri à Nova Viçosa pela BA 698 que está em ótimas condições.

As empresas de ônibus que atendem são a Santa Clara, Águia Branca e a São Geraldo. A Santa Clara faz os trechos mais curtos que são Nova Viçosa - Nanuque, Posto da Mata, 
Teixeira de Freitas e Itabatã. Já a Águia Branca faz os seguintes trechos: Salvador via Teixeira de Freitas - Nova Viçosa e Vitória e São Mateus - Nova Viçosa. Já a São Geraldo faz os trechos São Paulo, Rio de Janeiro, Belo Horizonte, Governador Valadares, Goiânia, Brasília e algumas cidades do Vale do Aço - Posto da Mata. Um dos problemas para o turista que chega a cidade de ônibus, é que a cidade de Nova Viçosa ainda não possui um terminal rodoviário o que dificulta um pouco o acesso do turista que tem que saltar em Posto da Mata e pegar outro ônibus pra chegar a cidade.

Não há acesso direto por avião para Nova Viçosa, mas para cidades próximas. Saindo de Salvador até Teixeira de Freitas, pela Linhas Aéreas Abaeté e saindo de São Paulo até Mucuri (aeroporto particular da Bahia Sul Celulose) pela Pantanal Linhas Aéreas. Como estes vôos não são em aviões de grande porte, se tornam muito caros, difícultando a comercialização de pacotes com acesso aéreo. A cidade possui também um porto onde é feito o acesso marítimo-fluvial.

\section{Abastecimento de água}

A água é sem dúvida nenhuma um dos recursos mais importantes na natureza. No turismo, este bem se torna ainda mais valioso, pois, na maioria das vezes serve não só para o abastecimento do local, mas também como atrativo natural. A preocupação com a poluição dos rios, do mar e do lençol freático deve ser constate, e o turismo deve desenvolver-se de forma a não trazer danos aos recursos hídricos.

Em Nova Viçosa, a captação para o abastecimento de água é feita do rio Pau Alto. A Empresa Baiana de Águas e Saneamento (EMBASA), atende parte do município e o resto é abastecido por poços artesianos (principalmente nos distritos). Em 2001, segundo dados da EMBASA existiam 5.565 ligações em todo município, uma relação de 5,9 pessoas por ligação. Observa-se, porém que em época de picos sazonais como carnaval e ano novo há falta de água na cidade. 
Em 2001, a qualidade da água do rio Peruípe foi considerada boa segundo relatório do Centro de Recursos Ambientais da Bahia (CRA), sobre a Bacia Hidrográfica do Extremo-sul da Bahia. Este rio é de extrema importância para a região, visto que este deságua no mar, formando o manguezal. É de extrema importância também para a economia local, pois, é utilizado para pesca, é navegável, sendo feitos inclusive passeios turísticos nele.

\section{Abastecimento de energia}

Segundo dados retirados do Rima da Aracruz Celulose ${ }^{6}$ em 2000, a rede de energia elétrica atende a quase todo município. O responsável pelo abastecimento na região é a Companhia de Eletricidade do Estado da Bahia (COELBA). Há pouco tempo atrás, a cidade de Nova Viçosa sofria constantemente com a falta de luz, o que trazia prejuízos consideráveis para o comércio e os serviços locais incluindo o turismo. Agora a COELBA está fazendo melhorias na rede e com isso melhorando o atendimento. Ainda assim, em época de picos sazonais, há falta de energia. O município é abastecido por energia elétrica gerada pela Usina de Funil, passando pelas subestações de Eunápolis, Teixeira de Freitas, Posto da Mata e de lá à Nova Viçosa.

\section{Abastecimento alimentício}

A cidade de Nova Viçosa, no verão, atrai grande número de turistas e chega até mesmo a duplicar sua população nesse período, e isso aumenta a demanda por bens e serviços. Segundo dados obtidos no Relatório de Impacto Ambiental (RIMA) da Aracruz Celulose ${ }^{7}$, os produtos alimentícios consumidos na região do extremo sul da Bahia vêm de diversos centros, em especial de Vitória, Rio de Janeiro e São Paulo, e secundariamente de Vitória da Conquista e Itamarajú. O município tem matadouro e o abastecimento de peixe, camarão e outros frutos do mar são fornecidos pela própria cidade.

\footnotetext{
${ }^{6}$ Aracruz Celulose, RIMA - Relatório de Impacto Ambiental Empreendimento Florestal no Extremo Sul da Bahia, agosto/2000. Pg 88.

${ }^{7}$ Idem. Pg 93
} 
$\mathrm{Na}$ realidade o turismo deveria incentivar a produção local, consumindo as frutas e verduras produzidas na região e dando prioridade para frutas típicas como caju, coco, dentre outras. Um problema típico trazido pelo turismo, e que em Nova Viçosa é muito comum, é que em alta temporada os preços dos produtos alimentícios aumentam bastante. A maior prejudicada nesses casos é a população local e um dos meios de minimizar este problema é diminuindo a sazonalidade que é muito forte na região.

\section{Esgotamento sanitário}

Segundo dados da Síntese do Diagnóstico da Costa das Baleias realizada pela FGV/HVS International para o PRODETUR NE - $\mathrm{II}^{8}$, não há tratamento do esgoto em nenhum dos municípios da Costa das Baleias e, além disso, é alto o índice de domicílios sem coleta de dejetos ou que utilizam fossas rudimentares. Isso pode provocar poluição hídrica, afetando não só a qualidade de vida dessas comunidades, como também prejudicando o futuro da atividade turística da região. Com o aumento do fluxo turístico, a situação tende a piorar se não forem tomadas providências.

Em Nova Viçosa, algumas poucas casas do centro da cidade ainda jogam o esgoto diretamente no rio Peruípe e o resto da cidade possui fossas sépticas ou rudimentares. De acordo com dados do Censo 2000, 64,9\% do esgotamento sanitário são fossas rudimentares, 4,6\% são fossas sépticas, 2,6\% são jogados no rio ou mar, 15\% não têm banheiro e apenas 12,9\% são atendidos por rede geral de esgoto (provavelmente no distrito de Posto da Mata). Estes dados são preocupantes visto que pode ocorrer contaminação do lençol freático e que algumas famílias ainda utilizam poços artesianos para o seu abastecimento de água.

\section{Resíduos Sólidos}

A coleta dos resíduos sólidos é feita pela Prefeitura Municipal de Nova Viçosa. O lixo é recolhido normalmente todos os dias sendo que a cidade foi dividida em dois lados (A e B) que se intercalam. No pico de temporada (carnaval e ano novo) em lugares de grande fluxo

\footnotetext{
${ }^{8}$ Pág. 12.
} 
turístico como, por exemplo, na praia do Lugar Comum, o recolhimento é feito de duas a três vezes ao dia, não chegando a ser suficiente. Nessa época, há limpeza da praia pela manhã e no final do dia. A Secretaria de Turismo e Meio Ambiente e o Departamento de Limpeza Urbana fazem mutirões de limpeza no porto, na orla e no canal do rio Peruípe. Infelizmente, ainda assim observa-se lixo na praia, sendo necessário uma campanha maior de educação ambiental tanto com a população local como os turistas.

O destino final do lixo era, até uns dois anos atrás, um depósito a céu aberto que ficava próximo ao manguezal. Felizmente a prefeitura mudou-o de local, e agora ao menos não está próximo a cursos d'água. No entanto, o destino final do lixo continua sendo um depósito a céu aberto e isso pode provocar a poluição do solo e proliferação de animais, como urubus e ratos, aumentando o perigo de doenças. A prefeitura tem intenção de fazer um aterro sanitário. Este aterro deve ser prioridade, pois com o aumento do fluxo turístico, há também um grande aumento da quantidade de lixo produzido, podendo vir prejudicar o meio ambiente e a saúde pública local.

\section{Circulação Interna}

Não há transporte público na cidade de Nova Viçosa. A cidade possui um táxi e não há locadoras de carro. Em Mucuri há uma pousada que faz este serviço de aluguel de automóveis e que leva o carro até Nova Viçosa a pedido do cliente. O que existe na cidade é aluguel de bicicletas, o que visto sob o prisma da conservação ambiental é bastante aconselhável e deve ser incentivado, pois a cidade é relativamente pequena. Este tipo de meio de transporte é bastante utilizado pelos moradores locais.

A estrada que liga Nova Viçosa à Mucuri vai até o começo da cidade, onde, acaba o asfalto e começa uma rua central de paralelepípedo (mão dupla) até o centro da cidade (parte histórica), a ruas periféricas são em sua maioria de terra batida. A cidade histórica foi toda pavimentada em bloquete e as obras do Bairro do Pescador (centro) estão em fase de conclusão. Outros projetos estão previstos, como a urbanização de parte da orla marítima. 
A sinalização viária e a sinalização turística são precárias, quando não inexistente. A Secretaria de Turismo do município de Nova Viçosa já tem um projeto de sinalização turística e de trânsito feito pela Secretaria de Estado em convênio com o Departamento de Trânsito da Bahia (DETRAN - BA). Ainda não há previsão para implantação do projeto, mas já foi dada entrada no pedido para execução junto ao Governo do Estado. Já foi feita uma despoluição visual, retirando placas, faixas e cartazes ao longo da Av. Oceânica e as novas placas foram padronizadas.

A sinalização deficiente tem trazido problemas. A falta de uma placa de sinalização na BR 101 mostrando que o acesso a Nova Viçosa passa por Mucuri, tem dificultado aos turistas achar a entrada da cidade. Já dentro da cidade, o principal centro de informações ao turista (o único que funciona o ano todo), localizado no prédio da Secretaria de Turismo, não possui nenhuma indicação, nem mesmo de onde fica a própria Secretaria de Turismo.

\section{Telecomunicações}

Quanto à rede de telefonia, a cidade possui 02 postos telefônicos e atende a telefonia celular. A prestadora local é a TELEMAR e o DDD do município é 73. No entanto, o município não tem estações de rádio ou TV. A cidade vizinha, Mucuri, possui rádio e é lá que são feitos os anúncios locais. O serviço de Correios atende a todo município com 2 agências e 1 caixa de coleta, sendo uma das agências na cidade de Nova Viçosa. O maior problema com relação às telecomunicações é a internet. A cidade ainda não tem provedores para internet. Os

provedores utilizados são os de Teixeira de Freitas, mas poucas pessoas têm acesso. No próprio governo municipal há dificuldade, quando não inexistência, de acesso à rede mundial.

\section{Segurança}

A cidade de Nova Viçosa possui uma delegacia de polícia e um posto da polícia rodoviária na entrada da cidade. Em época de alta temporada há aumento da criminalidade, principalmente assaltos. Outro grande problema é a prostituição, inclusive a infanto-juvenil. Estes problemas devem ser combatidos de forma incisiva. Não existe corpo de bombeiros no município, nem equipe de busca e salvamento. 


\section{Bancos e outros serviços}

Os bancos existentes no município são o Banco do Estado da Bahia (BANEB)/BRADESCO, Banco Cooperativo do Brasil (BANCOB) e Banco do Brasil (BB). A agência do Banco do Brasil fica em Posto da Mata. Na cidade de Nova Viçosa só tem caixas eletrônicos do Banco do Brasil, que se localizam em um posto de gasolina. Este talvez seja um dos piores problemas, pois às vezes falta dinheiro no caixa eletrônico. Como cidade turística, Nova Viçosa deveria ter uma agência do Banco do Brasil. A cidade possui oficinas mecânicas, borracheiros e 02 postos de abastecimento de combustível.

\subsection{OFERTA TURÍSTICA}

A oferta turística é composta pelos atrativos, equipamentos e serviços existentes em uma localidade, que são voltados para o turismo. Sem eles a atividade turística não pode se desenvolver. Compõem a oferta turística os serviços de meios de hospedagem, alimentação, agências e operadoras de turismo, transportadoras, entretenimento, dentre outros.

\section{Meios de hospedagem}

Em Nova Viçosa, foi observado um grande crescimento no número de meios de hospedagem. Para se ter uma idéia em 2000, o número de leitos da cidade era de 938, passando para 1965 leitos em 2001. Segundo dados colhidos na Secretaria Municipal de Turismo em 2003, a cidade possui 7 hotéis, 31 pousadas, 5 condomínios, 17 residenciais, 1 apart-hotel, 1 flat, 1 empreendimento com chalés.

Este número tende a aumentar mais ainda, pois um grande empreendimento está previsto para começar a ser construído agora em 2003, o do Condomínio Saratoga Iate Clube, onde estão previstos um condomínio residencial (venda de lotes), um hotel com aproximadamente 600 leitos (onde $50 \%$ serão comercializadas como apart-hotel preferencialmente para empresas e o restante vendido por cotas, onde o associado paga uma 
quantia por mês e tem direito a um período de hospedagem no ano). Isso é uma forma de quebrar um pouco a forte sazonalidade local.

O mesmo empreendimento contará ainda com um parque aquático (onde serão vendidos cotas e ingressos), e o clube terá ainda marinas, pista de Cooper, palco para eventos, lojas de conveniência, quadras de esporte e academia. O projeto todo está previsto para terminar em 2008 e conta com financiamento próprio, segundo entrevista com o Sr. Gustavo, dono do empreendimento.

Nova Viçosa possui também um hotel fazenda chamado Campo Grande, que dispõe de infra-estrutura para o turismo rural, como pesque-pague, trilhas em reserva florestal, clube de golfe e parques de lazer. Este mesmo hotel fazenda está com um projeto de fazer um Eco Village (já estão vendendo os lotes) e um Eco Resort, além disso, está em processo para se tornar uma Reserva Particular do Patrimônio Natural (RPPN), segundo dados da internet ${ }^{9}$.

Apesar desse crescimento, em Nova Viçosa ainda tem muito o chamado turismo de segunda residência. É grande o número de pessoas que tem casa na cidade, principalmente de Brasília, Goiânia e Minas Gerais. Este é um grande problema, pois apesar do turista ficar mais tempo na cidade, ele gasta bem menos e os meios de hospedagem ficam ociosos em certas épocas.

Nova Viçosa possui dois campings que oferecem boa infra-estrutura. Os hotéis são em sua maioria de nível correspondente ao três estrelas. Não existem ainda, hotéis quatro ou cinco estrelas na cidade. Nos picos de temporada, muitas vezes é insuficiente o número de leitos, visto que com a população flutuante o número de habitantes chega a dobrar e muitas famílias e turistas que possuem segunda residência alugam suas casas para temporada. Em baixa temporada os hotéis e pousadas ficam ociosos e alguns chegam até mesmo a fecharem suas portas.

\footnotetext{
${ }^{9}$ www.imoveisvirtuais.com.br/projeto.htm, consulta em 23 de maio de 2003.
} 


\section{Serviços de Alimentação}

Os restaurantes da cidade não são de categoria superior. São restaurantes simples que em sua maioria ou serve comida brasileira ou comida típica regional. Os quiosques, encontram-se na maioria das vezes na praia, onde são servidas bebidas e petiscos. As sorveterias em alta temporada costumam contratar mão-de-obra local para vender picolés (ambulantes) nas praias.

Em entrevista, a secretária de turismo Vanda Luzia, disse que os ambulantes são cadastrados pela Secretaria de Turismo, pagando uma taxa de 25 reais onde recebem um kit com duas camisetas e um boné, podendo trabalhar durante todo verão. A mesma Secretaria deu curso para estes ambulantes, em parceria com o Serviço Brasileiro de Apoio às Micro e Pe quenas Empresas (SEBRAE), de noções de higiene e qualidade no atendimento.

De acordo com dados da Secretaria de Turismo existem 22 quiosques cadastrados na Praia do Lugar Comum (nem todos em funcionamento). E, aproximadamente, 22 empreendimentos cadastrados como restaurantes, lanchonetes, pizzarias e churrascarias. A cidade também possui várias mercearias e 3 supermercados.

\section{Entretenimento}

A cidade tem pouca diversidade de entretenimento. Na Praça da Baleia, se encontram vários quiosques que vendem roupas, artesanato e principalmente souvenires. Alguns desses quiosques só abrem em alta temporada. Também em alta temporada, na mesma praça, tem barraquinhas que vendem comida e bebida e, em algumas ocasiões especiais é montado palco para shows. É na rua principal que cruza toda cidade que está quase todo o comércio local.

A cidade possui alguns campos de futebol. Na alta temporada eventualmente, são colocadas redes de vôlei na praia. Há um Centro de Treinamento de Professores, que é composto de biblioteca, auditório para 300 pessoas, quadras de esportes, área de lazer e sala de reunião. Nova Viçosa não possui cinema, teatro, boates ou casa de shows. Normalmente as 
festas e as atividades culturais são feitas na Praça da Baleia ou na praia (que tem um palco para shows na Praia do Lugar Comum).

Mesmo em alta temporada, a cidade não tem grande diversidade de entretenimento noturno, o lugar mais movimentado é a praia do Lugar Comum, onde os quiosques proporcionam algum divertimento, normalmente com som mecânico ou bandas regionais. Em alta temporada é montado um pequeno parque de diversões na cidade.

No carnaval, tem trio elétrico com bandas regionais e existem dois blocos carnavalescos: o Galera da Rapa, mais freqüentado pelos locais e o DK1 Beijo, pelos turistas. Através de entrevistas com a comunidade local, foi relatado que o carnaval de Nova Viçosa é mais curtido durante o dia, e de noite os turistas vão para a cidade vizinha Mucuri, que contrata artistas do cenário nacional como Araketu, KLB, Harmonia do Samba, dentre outros .

\section{Agenciamento}

Existem duas agências de viagens na cidade, cadastradas na EMBRATUR: a Costa Azul Turismo e a Atobá Turismo, que fazem passeios de barco a Abrolhos, Coroa Vermelha, Barra Velha e Caravelas. O passeio a Abrolhos, segundo pesquisa feita in loco em fevereiro de 2003 , custa por volta de $\mathrm{R} \$ 160,00$ por pessoa, sendo feito em lancha com direito a lanche, taxa do Instituto Brasileiro de Meio Ambiente e dos Recursos Naturais Renováveis (IBAMA), material de mergulho (máscara e snokel) e tem duração de 01 dia (saída com no mínimo 8 e máximo de 15 pax).

A Atóba Turismo tem um sistema de parceria com a Abrolhos Turismo, da cidade de Caravelas, para os passeios para Abrolhos. No caso das duas ou uma das duas não ter o número mínimo de passageiros para o passeio, elas entram em contato uma com a outra e se juntam para leva-los a Abrolhos. O mesmo acontece com os clientes interessados em praticar mergulho autônomo e fazer cursos de mergulho, visto que, dentre as duas, somente a Abrolhos Turismo presta este serviço. 
O passeio a Coroa Vermelha fica por $\mathrm{R} \$ 45,00$ por pessoa, Barra Velha fica por volta de $\mathrm{R} \$ 20,00$ e Caravelas sai por aproximadamente $\mathrm{R} \$ 40,00$ por pessoa. Normalmente os passeios são feitos de barco ou escuna e tem duração de 01 dia (sempre saindo de manhã bem cedo 7:00h e chegando antes de escurecer às 17:00h) sendo que os dois últimos são pelo rio e Coroa Vermelha é marítimo.

Nenhuma das agências oferecem city-tour e a cidade não possui guias locais. Isso empobrece muito a experiência turística, pois apesar de haver visita a lugares lindos como a ilha de Barra Velha, não há qualquer tipo de interpretação ambiental ou cultural do lugar. A Costa Azul Turismo aluga equipamentos para mergulho completo, mas somente para quem já tem curso de mergulho. Os equipamentos também podem ser alugados para pessoas interessadas em fazer o "batismo" desde de que sejam acompanhadas por um instrutor (eles também oferecem este serviço).

\section{Outros serviços}

A cidade possui um posto de informação turística permanente, que fica na Secretaria de Turismo, que funciona em horário comercial de segunda à sexta. $\mathrm{O}$ grande problema deste posto é que não há sinalização informando, nem sobre o posto de informação turística nem aonde é a Secretaria de Turismo. Durante o verão (final de dez à segunda semana de fevereiro) é colocado mais um posto de informações na praia do lugar comum.

Durante os picos sazonais que são ano novo e carnaval, ainda é colocado mais um posto na entrada da cidade junto ao posto da polícia rodoviária, quando são distribuídos kits com sacolas de lixo, informações sobre a coleta de lixo local, da importância do uso do preservativo, dentre outros. Em alta temporada, encontra-se nas praias jet-ski e banana boat para alugar. 


\section{Qualificação profissional para o turismo}

A grande maioria das pessoas que atuam na área do turismo em Nova Viçosa não possui cursos na área. São pessoas que montaram o empreendimento turístico no local e administram sem ter experiência anterior no negócio.

Um dos problemas mais apontados pelos donos de hotéis e pousadas entrevistados é justamente a falta de qualificação da mão-de-obra local. No ano passado foi dado o curso de camareira, qualidade no atendimento e gestão empresarial do SEBRAE, os próximos serão os de técnicas em vendas, balconista e o de Ecoturismo que será dado pelo Sindicato Rural de Itamaraju.

A qualificação da mão-de-obra tem que ser prioridade no turismo. As pessoas gostam de ser bem atendidas, principalmente quando estão de férias e a última coisa que querem é se aborrecer com serviços mal prestados, ou promessas não cumpridas.

O setor de serviços em turismo tem uma particularidade quanto aos produtos que oferece: a produção e o consumo acontecem ao mesmo tempo. Se ocorrer um erro não há como disfarçar-lo ou consertar-lo. No turismo isso se torna ainda mais crítico, pois estamos lhe dando diretamente com sonhos e expectativas distintas. Cada turista trás consigo uma carga cultural diferente e, conseqüentemente tem expectativas diferentes.

\subsection{TURISMO RECEPTIVO}

Os dados coletados nas pesquisas da demanda são de extrema importância para o planejamento do turismo e para direcionar o plano de marketing local. Através dessa pesquisa é possível conhecer o tipo de turista que visita a cidade, e dar novos rumos ou continuar com o mesmo segmento de mercado. 
Segundo pesquisa realizada pela Empresa de Turismo da Bahia (Bahiatursa) ${ }^{10}$ do turismo receptivo nos municípios de Mucuri/Nova Viçosa no período de janeiro e julho/2000, praticamente não existe fluxo de turistas estrangeiros. O perfil do turista que visita esses municípios é de turistas brasileiros, sendo a maioria de homens e a maior parte tem idade entre 26 e 50 anos. A maior parte é de Minas, seguido pelo Espírito Santo, Brasília (janeiro) e São Paulo (julho).

O perfil do visitante que visita a cidade no verão é um pouco diferente do que visita em julho. O turista que vem em julho quer avistar as baleias Jubarte e participar da Festa da Baleia, sendo um turista mais ligado ao ecoturismo. O turista que vem no verão é aquele que busca mais a praia.

Os principais motivos de viagem à Nova Viçosa são o lazer, sendo a principal motivação de passeios os atrativos naturais ( $96 \%$ em janeiro), seguidos por motivo de visita a parentes e amigos ( $6 \%$ em janeiro) e negócios (a maioria deve ser para o município de Mucuri por causa da Bahia Sul Celulose). A grande maioria dos turistas não teve viagem organizada por agência ( $99 \%$ janeiro e $96.3 \%$ julho) e que o que mais influenciou na decisão da visita foi porque já conhecia ou pelos comentários de amigos e parentes.

Nos dados acima, existem dois pontos mais importantes e que devem ser trabalhados no plano de marketing local: o primeiro é que o turista não utiliza os serviços de agência e o outro é que ele vem à Nova Viçosa por recomendação de amigos ou por já conhecer. Isso confirma dados apurados em campo de que a cidade não possui um marketing efetivo. $\mathrm{Na}$ realidade a promoção da cidade é quase inexistente.

O meio de transporte mais utilizado para chegar a cidade foi o automóvel, seguido do ônibus. Os meios de hospedagem mais utilizados são casa própria (aprox. 32\%), casa de parentes/amigos (aprox. 26\%), casa alugada (janeiro 19\%), pousada (julho 25,9\%). Mais uma vez as estatísticas confirmam que os turistas das duas temporadas se diferenciam e que o de

\footnotetext{
${ }^{10}$ Bahiatursa, Sinopse - Pesquisa de Turismo Receptivo Nova Viçosa/Mucuri, jan e jul/2000.
} 
julho utiliza bem mais os meios de hospedagem. O tempo de permanência médio do turista é de 10,7 dias em janeiro e 6,7 dias em julho.

Este perfil de turista pode trazer grandes problemas para o desenvolvimento do turismo municipal. O turista de segunda residência gasta menos apesar de ficar mais dias, pois não utiliza os meios de hospedagem e muitas vezes preparam a comida em casa. Com isso, o município recebe menos divisas, emprega menos, e pode ainda sofrer com a especulação imobiliária.

Um dado bom é que $97 \%$ dos turistas pretendiam voltar a visitar o município. O que mais agradou aos turistas foram às praias seguido da hospitalidade. $\mathrm{O}$ que mais desagradou foi à limpeza pública. Esses dados são de extrema importância para saber qual o diferencial da cidade, que no caso de Nova Viçosa é a hospitalidade de seu povo. E claro, sanar ou minimizar os principais problemas apontados, que no caso é a limpeza pública deficiente.

O município de Nova Viçosa, como toda Costa das Baleias, sofre bastante com a sazonalidade, os principais picos sazonais são o Ano Novo e o Carnaval, e as épocas do ano que o fluxo turístico é mais intenso é de dezembro à fevereiro e em julho com a Festa da Baleia. A cidade vem crescendo como pólo turístico, e o turismo de praia é o mais desenvolvido no local.

\subsection{ASPECTOS NATURAIS DA REGIÃO}

Como se pode perceber pela pesquisa acima, o fator que mais chama atenção dos turistas que visitaram Nova Viçosa são seus recursos naturais. Os recursos naturais têm grande destaque no turismo e, a própria atividade turística pode contribuir para que esses recursos sejam preservados e mantidos para as futuras gerações. Para que isso ocorra, faz-se necessário que os recursos sejam bem trabalhados e interpretados, educando o turista e a comunidade local. 


\section{Geomorfologia}

Segundo dados do Rima da Aracruz Celulose ${ }^{11}$, são duas unidades morfológicas distintas, os Tabuleiros Costeiros que se caracteriza por apresentar um relevo plano e de topografia monótona. E as Planícies Costeiras, esse tipo de relevo ocupa uma posição intermediária entre os Tabuleiros Costeiros e o Oceano Atlântico, é de uma forma geral plano, com baixa declividade e altimetria entre 0 a 15 metros. As unidades geológicogeomorfológicas presentes na planície costeira são: Terraços Arenosos Internos; Terraços Arenosos Externos; Terraços Argilosos; Manguezais/Planície de Maré e Brejos e Pântanos.

\section{Clima}

O tipo climático da região é o sub-úmido e úmido. A temperatura média anual é de $24,4^{\circ} \mathrm{C}$, com máxima de $26,9^{\circ} \mathrm{C}$ e mínima de $22,7^{\circ} \mathrm{C}$. O que torna o clima agradável o ano todo, favorecendo o turismo. O período de maior insolação na região, acontece nos meses de janeiro, fevereiro e março. A média anual de umidade relativa é de $87,1 \%$. A região do Extremo Sul da Bahia caracteriza-se por precipitações superiores a $1000 \mathrm{~mm}$ A velocidade média do vento na região é de $3 \mathrm{~m} / \mathrm{s}$ com direção predominante E-SE.

\section{Vegetação}

A vegetação pode se tornar um grande atrativo em Nova Viçosa (atualmente não é bem aproveitado) visto que no município ainda se encontram remanescentes de mata atlântica, além é claro de ter um grande manguezal, o maior em biodiversidade da Bahia. Os dados do RIMA da Aracruz Celulose, relatam que a formação vegetacional original é a Mata Atlântica, com seus ecossistemas associados. Há Formação de diferentes regiões fitoecológicas no Extremo Sul da Bahia, como:

- Floresta Ombrófila Densa (em estágio avançado, médio e inicial) com espécies como: pau-brasil, jacarandá-da-bahia, sucupira, parajú, maçaranduba, aderno, cedro,

\footnotetext{
${ }^{11}$ Idem. Pg 46 a 54.
} 
louro-prego, piqui-preto, braúna, sucupira, pau d'arco, murici, dedenzeiro, dentre outras.

- Restingas, com espécies como: murta, cajueiro, salsa, cardo santo, bromélias e lixeira.

- Mussunungas/brejos e alagados, com espécies como: sempre vivas, tiriricas, marcela e palmeiras (mussunungas), taboa e o junco (brejos).

- Manguezal, ambiente de grande importância ecológica e econômica, pois é nele que grande parte dos animais marinhos encontra abrigo e alimento. A sua flora é pouco diversificada só existindo praticamente o mangue vermelho, mangue branco, Siriba e mangue de botão.

Das espécies raras, endêmicas ou em vias de extinção, são raros o pau-de-cachimbo e o buranhém. Enquadradas na categoria Em Perigo (em vias de extinção) de espécies protegidas pelo IBAMA, está o pau-brasil. Na categoria Vulnerável esta o jacarandá-da-bahia e a braúna. Como endêmicas da área existem 02 espécies de óleo-corumbá.

\section{Fauna}

A fauna da região é muito rica, principalmente a fauna marinha. É grande a importância dos peixes para o homem, principalmente como alimento. A abundância de corais e a presença de manguezal propiciam a diversidade das espécies aquáticas. Havendo assim, um grande potencial para o mergulho e para a pesca amadora. $\mathrm{O}$ grupo de crustáceos tem grande importância ecológica e econômica para a região. Os camarões rosa, sete barba e verdadeiro, juntamente com os caranguejos, guaiamu, siri e lagostas, merecem destaque, pelo seu número e pelo seu largo emprego alimentar. Outro grupo de invertebrados de importância é representado pelos moluscos, dentre os quais destacamos o sururu e a ostra do mangue.

$\mathrm{Na}$ região do extremo sul da Bahia, segundo o Rima da Aracruz Celulose, os mamíferos estão diretamente relacionados com o tipo de vegetação local e o desmatamento constituí o maior fator de risco para este grupo na região. Foram registradas 48 espécies de mamíferos na região. Dentre os quais está a Preguiça, o mico da Cara Branca e a baleia Jubarte. 
$\mathrm{Na}$ área em estudo, apesar do alto grau de alteração ambiental, foi encontrada uma grande diversidade de aves endêmicas, ameaçadas de extinção, raras, ocasionais e migratórias, tais como: o fura-mato, araponga, pariri-vermelha, tiê, andorinhão, gavião-pombo, papagainho, bico-de-veludo, sofrê, sabiá-uma, sabiá-poca e as andorinhas. Essa diversidade de aves pode abrir novas oportunidades de negócios no futuro, trazendo o segmento de observadores de pássaros para a região. Mas este segmento deve ser trabalhado com muito cuidado, pois é bem específico e exige o acompanhamento de especialistas.

Particularmente comuns, na região em estudo, são algumas espécies de serpentes peçonhentas, notadamente a jararaca e a surucucu-pico-de-jaca, que se encontram na Lista Oficial de Espécies da Fauna Brasileira Ameaçadas de Extinção. Ao se desenvolver o ecoturismo na região deve-se ter os cuidados necessários para que não ocorram acidentes fatais. Os anfíbios representam um elo importantíssimo na cadeia alimentar de muitos animais. Ovos de certos anfíbios são predados e animais adultos, principalmente de pequeno porte, têm papel importante na alimentação de numerosas espécies de cobras, tartarugas, mamíferos e aves ribeirinhas.

\section{Recursos Hídricos}

O principal rio do município é o Rio Peruípe, considerado de médio porte e que deságua no oceano Atlântico. É navegável por embarcações de médio e pequeno porte. A qualidade de sua água é boa, e o fato de ser navegável faz com que ele possa ser aproveitado para passeios turísticos. Apesar de já existirem passeios desse tipo, esses têm pouca procura atualmente. Talvez se os passeios fossem mais bem formatados, com interpretações ambientais e histórico-culturais, além de uma divulgação maior deste produto, a procura aumentasse. 


\section{Tipificação da paisagem}

A paisagem da cidade de Nova Viçosa é tipicamente costeira, são 30km de praia (as praias mudam de nome conforme os trechos, mas é a mesma praia) e na maré baixa chega a ter até 300m de largura. Quanto mais próxima da cidade maior é a descaracterização em relação à paisagem original.

Nas praias mais próximas da cidade, as construções são a beira mar (casas, pousadas, hotéis, barraquinhas, etc.), mas apesar disso a maior parte ainda apresenta ou vegetação rasteira ou coqueirais na frente das construções. Essas construções normalmente não são muito altas não passando de 03 andares. Quanto mais afastadas da cidade mais conservadas se encontram as praias. A praia da Costa do Attântico é refúgio das tartarugas marinhas para postura de ovos.

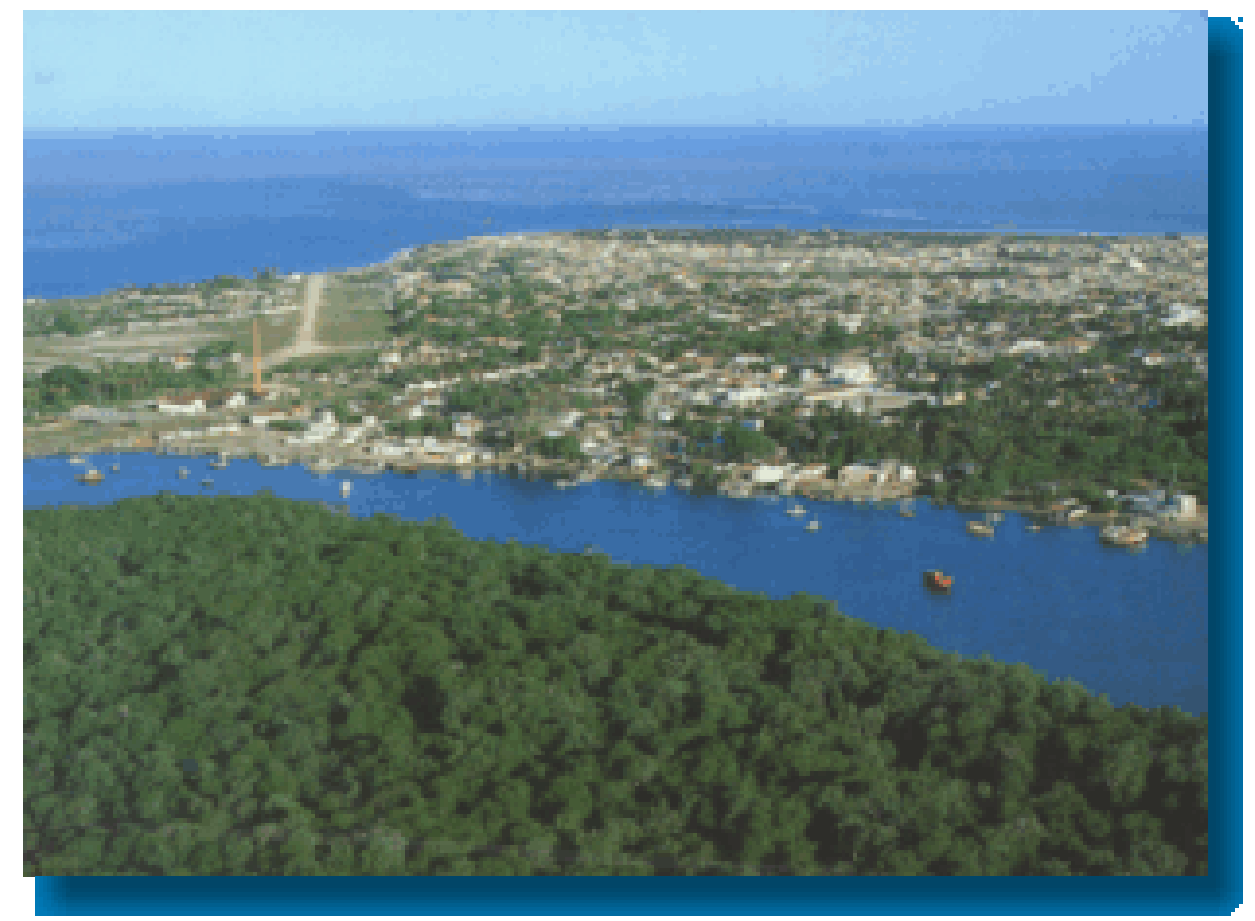

Figura 1 - Foto aérea de Nova Viçosa (Foto: Amaral ${ }^{12}$ )

\footnotetext{
${ }^{12}$ Fotos retiradas do site www.abrolhos.com.br, em 23 de maio de 2003.
} 
O manguezal, com suas árvores de raízes aéreas, abriga grande quantidade de espécies típicas deste habitat. É um dos mais importantes manguezais em termos de biodiversidade da Bahia. Nova Viçosa possui ainda áreas de Mata Atlântica, onde encontram-se variedades de frutas nativas como mangaba, caju, dentre outras e também variedades de orquídeas e bromélias. Todo esse potencial deve ser mais bem trabalhado para o turismo. A formatação de pacotes, com guias especializados na fauna e na flora locais, deve ser prioridade para o desenvolvimento do ecoturismo.

\subsection{ATRATIVOS TURÍSTICOS}

\section{Atrativos Naturais}

$\mathrm{O}$ atrativo natural mais divulgado e visitado em Nova Viçosa são suas praias. $\mathrm{Na}$ realidade a praia é uma só, longa, que muda de nome diversas vezes. Suas águas são limpas, porém turvas, mas a temperatura da água é bastante agradável aos turistas.

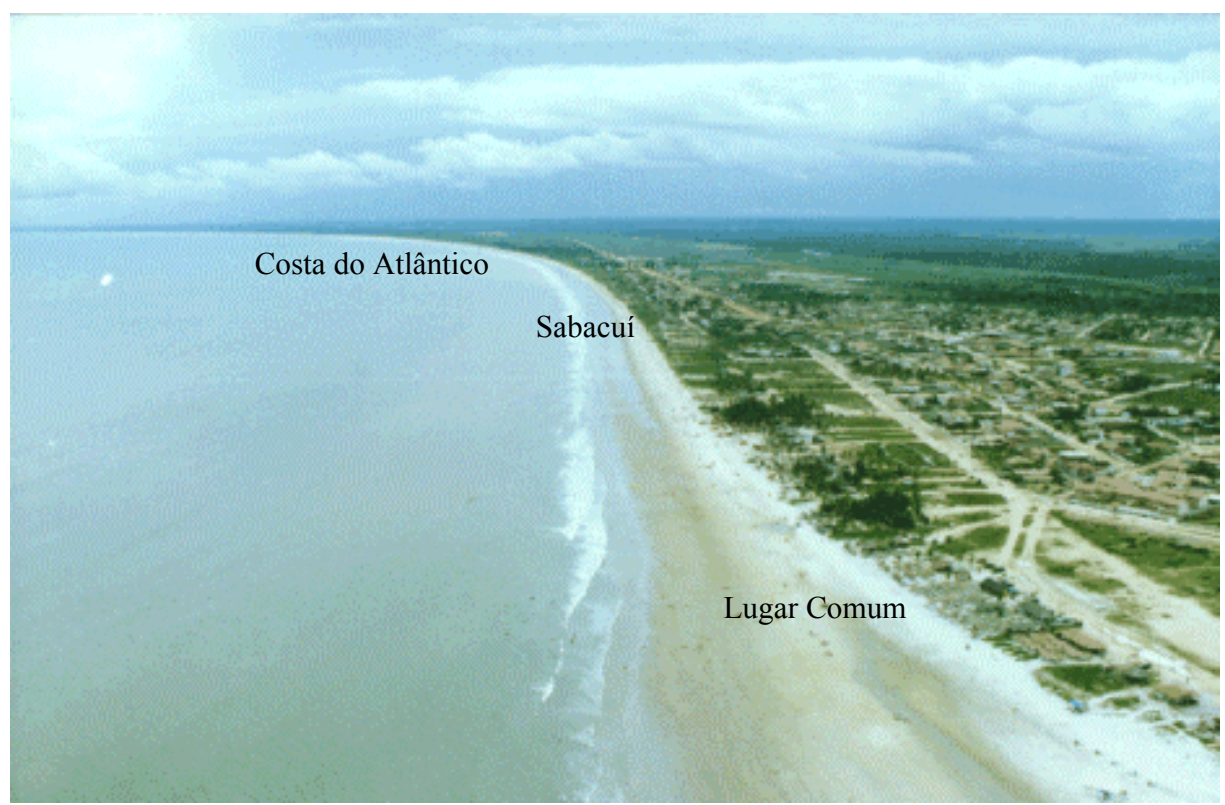

Figura 2 - Foto aérea das praias de Nova Viçosa - BA (foto: Amaral) 


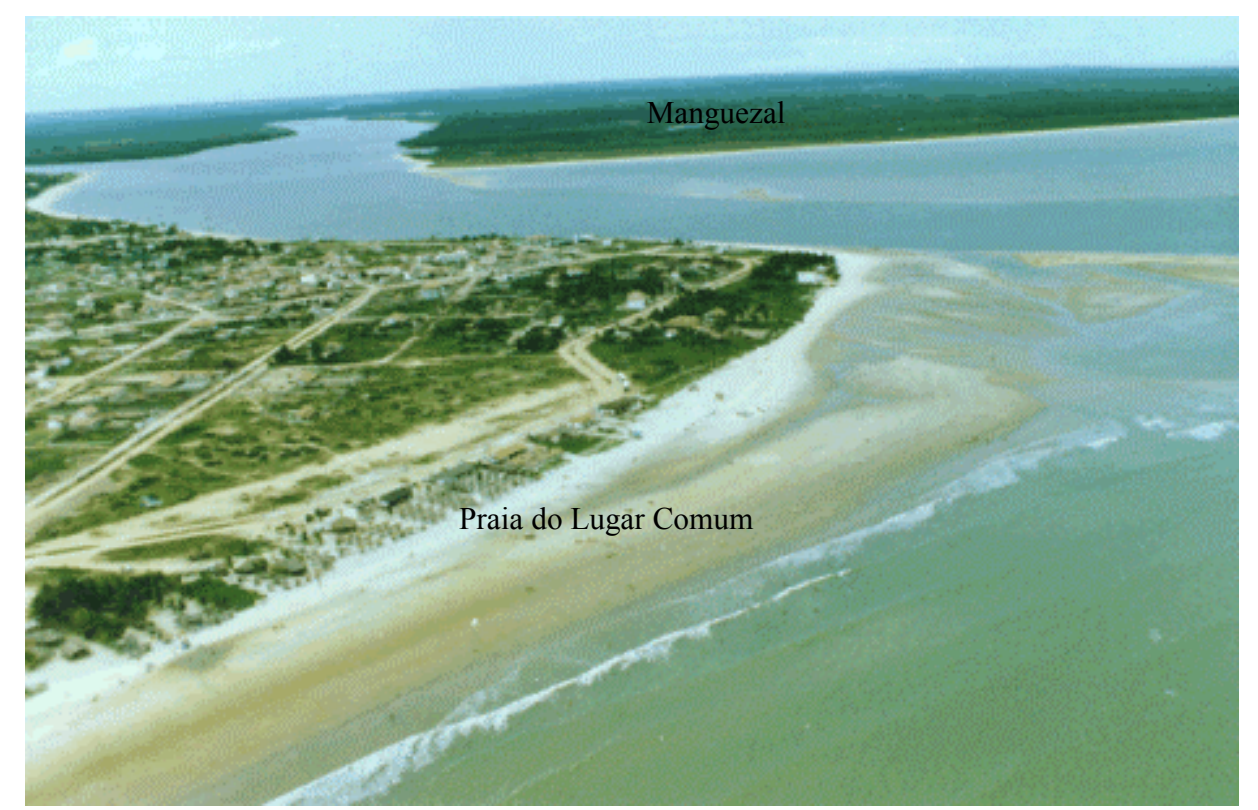

Figura 3 - Foto aérea encontro do Rio Peruípe com o Oceano (Foto: Amaral)

A Costa do Atlântico é a praia mais distante do centro urbano, de ondas fortes, areia grossa, búzios e coqueiros. É refúgio das tartarugas marinhas para sua postura e cria, onde vive uma comunidade de pescadores que ainda utiliza a pesca artesanal. Esta praia está em muito bom estado de conservação. Já que o projeto Tamar tem uma sede no município, a visitação a esta praia deveria ser orientada por eles, para que os turistas não causem maiores danos ambientais e possam conhecer melhor o trabalho deste projeto.

A Praia do Sabacuí é uma enseada de ondas mansas. Extensa, com búzios sobre a areia fina e solta. Possui vegetação rasteira e coqueiros. Em sua orla estão localizadas casas, pousadas, campings e hotéis. É uma das melhores, mas não é muito movimentada. A Praia do Pau Fincado é relativamente movimentada, reúne barracas, é reta, de ondas fracas e areia batida. Possui as mesmas características da praia do Sabacuí.

A Praia do Lugar Comum é urbana, localiza-se a dois quilômetros do centro da cidade. É onde se encontram a maior parte das barracas, e no verão, é o lugar mais movimentado, tanto de dia quanto de noite, aonde acontecem os shows e lual nas barracas. A Praia do Pontal da Barra é a primeira no perímetro urbano. Fica na foz do Rio Peruípe e, na maré baixa, forma um banco de areia de mais de duzentos metros entre o mar e o rio. A temperatura da água é 
morna e a areia é monazítica, indicada para tratamentos de reumatismo. Tem ondas fracas, coqueiros, pitangueiras e cajueiros. É boa para pesca.

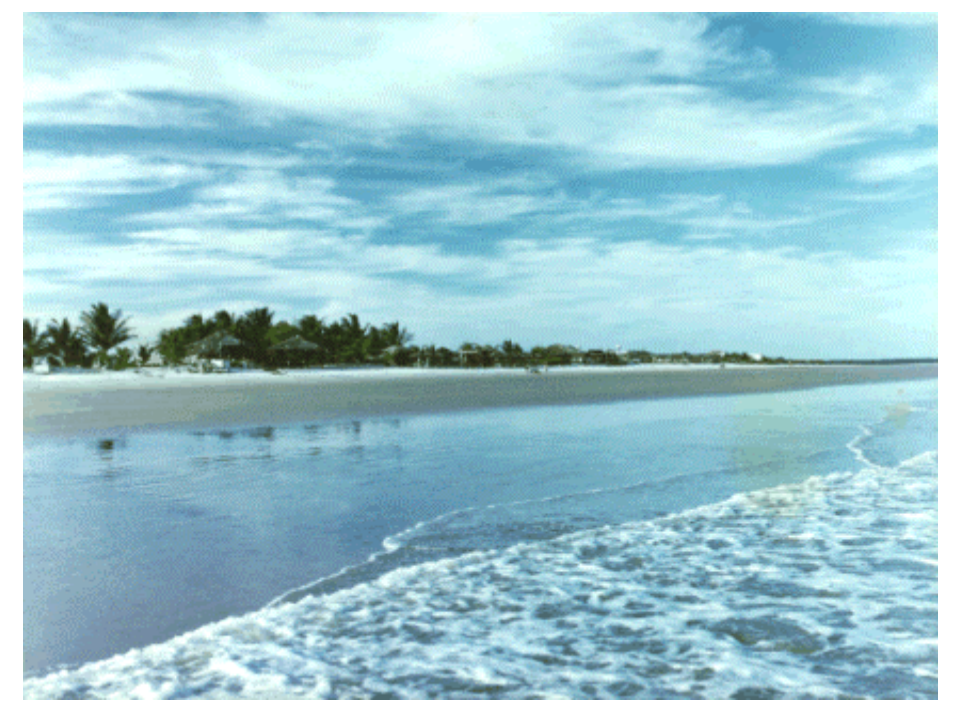

Figura 4 - Praia do Lugar Comum (Foto: Arquivo Goiás Praia Hotel)

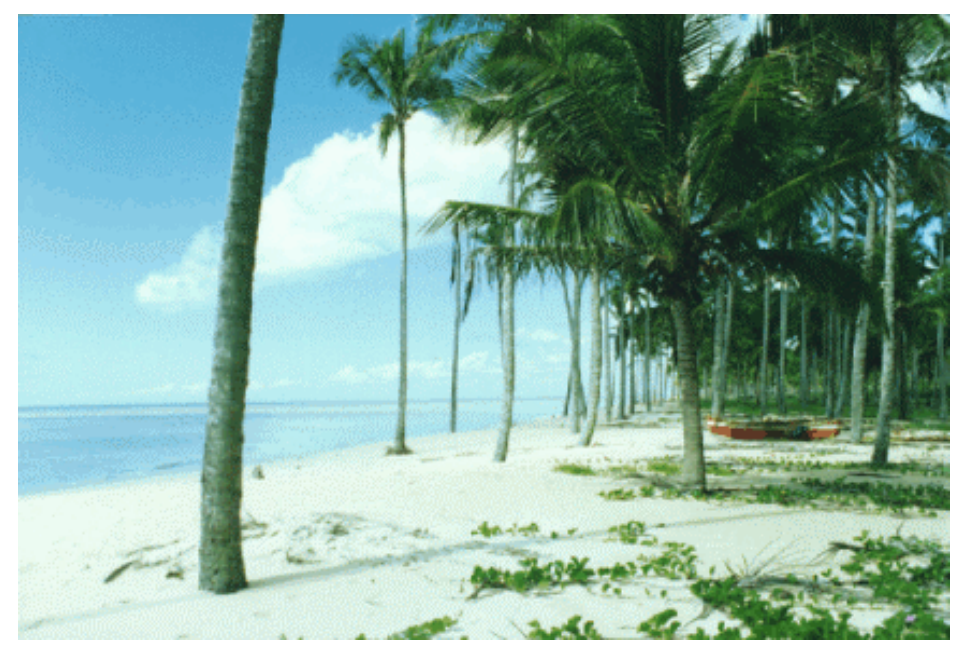

Figura 5 - Ilha de Barra Velha (Foto: Amaral)

As ilhas são outro atrativo muito visitado, principalmente a ilha de Barra Velha. Deserta, esta ilha fica a 40 minutos de barco ou escuna do porto (15 min.de lancha) seguindo o Rio Peruípe, no passeio pode-se contemplar o manguezal. De um lado da ilha encontra-se o rio e o mangue, do outro o mar aberto. A ilha é ainda habitada por pescadores, não possuindo eletricidade (somente geradores). Passeios de um dia são feitos pelas agências de viagens e 
pescadores de Nova Viçosa, o almoço é preparado por dois moradores locais, que o fazem sob encomenda. Esse é um dos atrativos que podem ser mais bem trabalhados, contratando-se guias locais (da ilha mesmo), vendendo artesanato feito pela população local. O produto precisa ser melhor formatado.

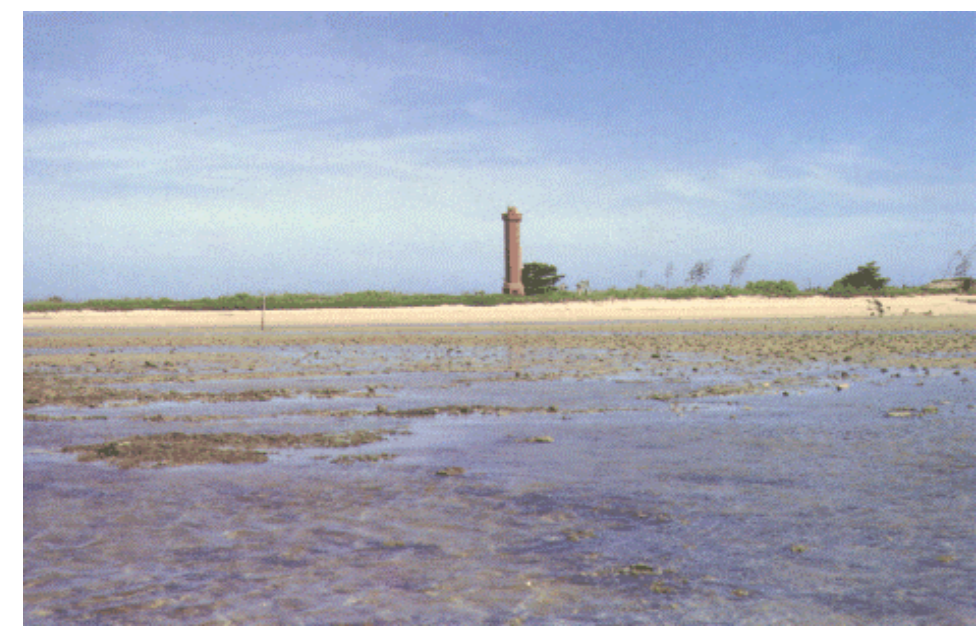

Figura 6 - Ilha de Coroa Vermelha (Foto: Amaral)

A Ilha de Coroa Vermelha é uma ilha arenosa, topo de um antigo recife de coroa, em pleno oceano, fica a 30 minutos de lancha do porto. Não possui qualquer infra-estrutura, apenas um farol e um barraco pequeno abandonado. Na maré baixa aparecem várias piscinas, proporcionando a visualização de algas, tartarugas marinhas, peixes diversos, estrelas do mar, dentre outros. É excelente para pesca e mergulho. Outro atrativo que tem potencial para o mergulho e para pesca é o Recife Sebastião Gomes.

A Ilha Cassunda é um verdadeiro complexo hídrico/ecológico onde um emaranhado de rios, lagoas e braços de mar misturam sua águas às margens de uma das maiores áreas de manguezal da Bahia. Situada às margens dos rios Peruípe, Caravelas e Pitu-açu, entre os municípios de Nova Viçosa e Caravelas, a Ilha Cassumba, possui 250 famílias residentes, distribuídas em pequenas vilas. As praias são semi-desertas. O acesso é fluvial e dura cerca de 40 minutos de barco. Este produto de grande potencial, praticamente não é divulgado em Nova Viçosa (O município de Caravelas é que trabalha mais com este produto turístico). 


\section{Unidades de Conservação}

Em áreas próximas à cidade de Nova Viçosa existem várias unidades de conservação, no entanto hoje, só o Parque Nacional Marinho de Abrolhos é mais divulgado e vendido, assim mesmo, apesar de Nova Viçosa ser o local mais próximo de Abrolhos, Caravelas é que é conhecida como portal de saída para o Parque Nacional Marinho de Abrolhos. As unidades de conservação são importantes para garantir a preservação das espécies locais, mas é por isso mesmo que devem ser mais divulgadas e visitadas, se a lei assim o permitir, pois as pessoas costumam respeitar, contribuir e lutar muito mais por aquilo que elas conhecem.

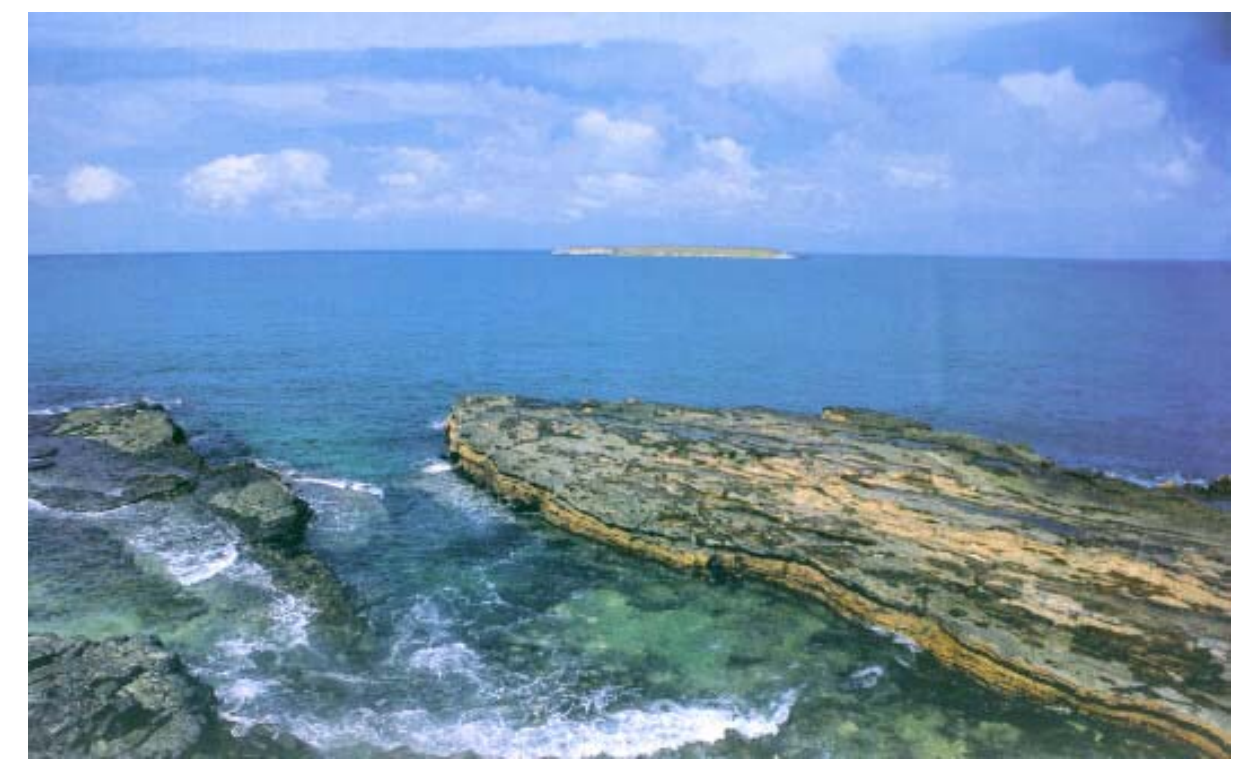

Figura 7 - Parque Nacional Marinho de Abrolhos

O Parque Nacional Marinho de Abrolhos foi criado em 06 de abril de 1983, e é monitorado pelo IBAMA. Foi o primeiro Parque Nacional Marinho do Brasil. Sua área total é de $910 \mathrm{~km}^{2}$, o arquipélago de Abrolhos é composto por cinco ilhas:Santa Bárbara (pertencente a Marinha do Brasil), Redonda, Siriba, Guarita e Sueste. Abrolhos situa-se a cerca de $65 \mathrm{~km}$ de Nova Viçosa, suas águas não são muito profundas (daí veio o nome Abrolhos "abra os olhos") fazendo com que algumas embarcações naufragassem na região. 
Em Abrolhos são encontradas todas as espécies de corais recifais que ocorrem na costa brasileira, e algumas espécies que só existem naquela região como é o caso do coral Mussismulia brasiliensis (o cérebro). Lá podem ser encontradas uma grande diversidade marinha, são esponjas, algas, corais, moluscos, peixes diversos, tartarugas, arraias, moréias, além das baleias Jubarte que migram para esta área anualmente para reprodução entre os meses de julho e novembro.

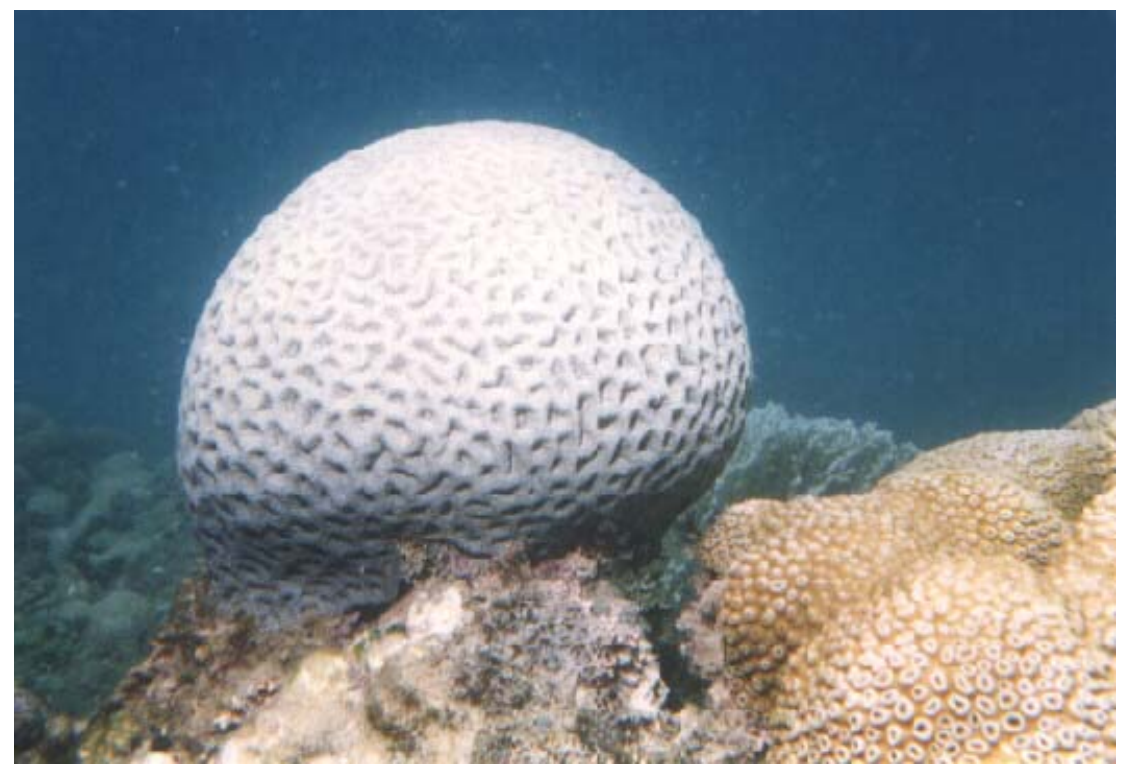

Figura 8 - Coral Mussismulia brasiliensis (O Cérebro)

Além disso, o arquipélago também abriga variadas aves marinhas (a grande maioria migratória). Já foram identificadas 26 espécies, sendo que apenas quatro são residentes: o atobá branco, o atobá marrom, a grasina e a fragata. Abrolhos é considerado um dos 10 melhores locais para mergulho do mundo. São proibidas a caça e a pesca ou qualquer tipo de coleta e não é permitido pisar nos corais.

Nova Viçosa tem um Parque Ecológico Municipal que é uma reserva natural, que abriga parte remanescente da Mata Atlântica, manguezal e restingas e que conta com as ilhas de Barra Velha e Coroa Vermelha. O parque possui uma rica fauna conta com peixes diversos, crustáceos, aves migratórias, micos da cara branca e preguiças. 
$\mathrm{Na}$ flora destacam-se bromélias, em grande variedade e cactos. É um local caracterizado pelo encontro da mata com o mangue. Apesar disso, os passeios que existem são apenas os de Coroa Vermelha e Barra Velha. Não existe no local um passeio com guia pela mata atlântica ou pelo manguezal.

Em seu território também encontra-se parte da APA Estadual Ponta da Baleia, que abrange os municípios Alcobaça e Caravelas. Esta APA tem as mesmas características de fauna e flora do Parque Ecológico Municipal.

Como observado, a cidade possui um grande potencial ecoturístico, que, no entanto não vem sendo bem trabalhado. Não possui passeios que utilizem os princípios do ecoturismo como base, não existe interpretação ambiental, nem educação ambiental (com exceção de Abrolhos). Ou seja, atrativos que poderiam estar gerando renda para populações tradicionais, não tem sido bem aproveitados.

\section{Atrativos histórico-culturais}

De um modo geral, os monumentos e a cultura locais não são divulgados. Não existe nenhum produto formatado nesse sentido, os turistas que visitam os monumentos o fazem por conta própria. A Secretaria de turismo está com um projeto de restaurar a parte histórica da cidade, mas não há previsão de quando isso vai ocorrer. A história local é muito rica. Segundo dados da Secretaria de Turismo e Meio Ambiente, o centro histórico de Nova Viçosa é datado de 1720 e pelos documentos históricos, é provável que no local tenham vivido tribos dos Botocudos e Machacalis.

Segundo estes documentos, o distrito de Helvécia foi colonizado por suíços e alemães que utilizavam a mão de obra escrava. Quando os estrangeiros foram embora, os negros firmaram sua comunidade na localidade, criando um quilombo. Até hoje encontram-se fortes vestígios desta cultura, como por exemplo a senzala. 
Os principais monumentos históricos do município de Nova Viçosa são a Casa de Câmara e Cadeia que foi criada no final do século XVIII, onde hoje se encontra a Secretaria de Turismo e Meio Ambiente. A Matriz de Nossa Senhora da Conceição, criada também no final do século XVIII, é um edifício com programa constituído de nave, capela mor, torre com acesso externo e terminação piramidal. Outra construção importante é a Estação Ferroviária, que fica no Distrito de Helvécia e a data de sua criação é de 1897. É um edifício com planta retangular, constituída por dois corpos justapostos: o da direita, térreo servia de armazém e o da esquerda, assobradado, abrigava a administração e estar dos passageiros.

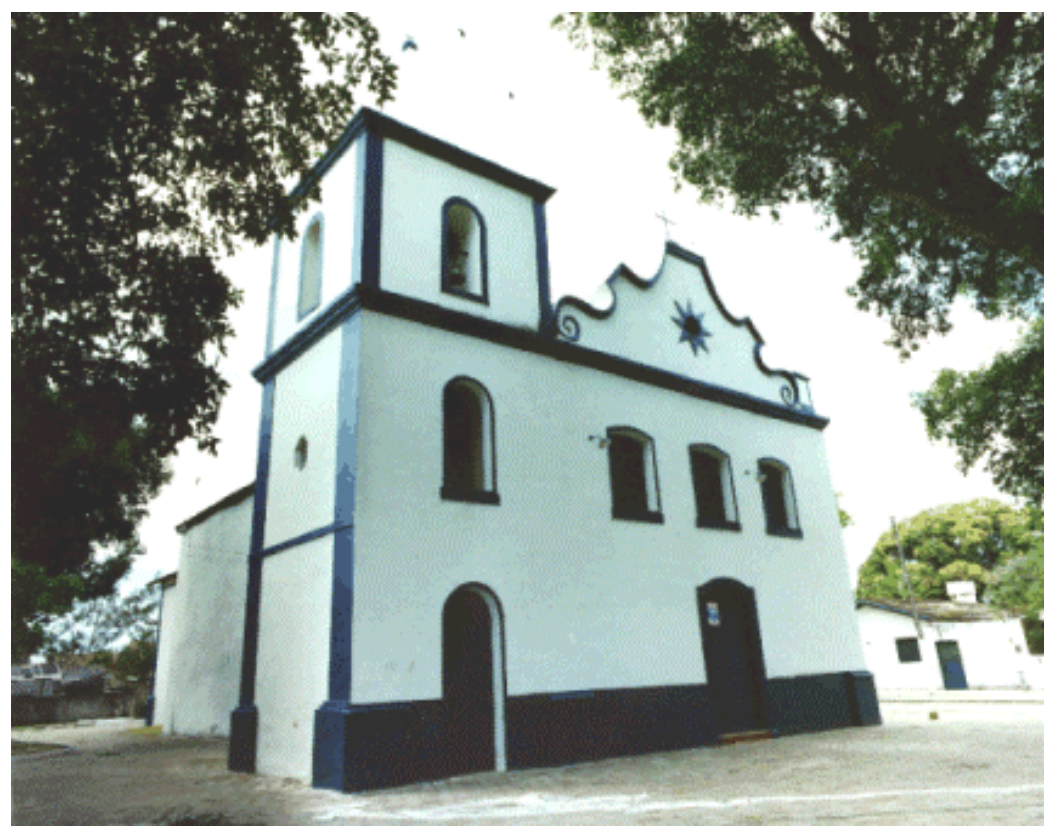

Figura 9 - Matriz de Nossa Senhora da Conceição (Foto: Arquivo Goiás Praia Hotel)

\section{Tradições Locais}

As tradições que apresentam maior interesse para o turismo são: o Bate Barriga, que acontece em Helvécia. Trata-se de um grupo bastante característico, em que uma parte é formada por homens bate tambor, enquanto duas mulheres batem coxa contra coxa. Posteriormente, dois homens entram na roda e tiram músicas enquanto fazem versos.

A Festa do Boi Janeiro que é uma variação do Bumba-meu-boi em Nova Viçosa. Trata-se de uma pessoa vestida de boi, situada no interior de uma roda de curiosos. O Boi sai 
dando cabeçadas, assustando e pondo as pessoas para correr. Outras personagens são a Mãe Catita, A Urubutinga e a Baliza.

Outros eventos culturais de interesse turístico são a festa de Iemanjá na virada do ano e a festa de São Pedro, que é realizada no rio Peruípe, Barra e vias públicas, no dia 29/06. Esta última é uma festa organizada pela comunidade de pescadores, que consta de procissão fluvial e marítima, caracterizada por barcos embandeirados. O cortejo desce o rio Peruípe, contornando a Barra e retornando a origem. Ao desembarcar, ocorre uma nova procissão, esta feita pelas ruas da sede.

O Forró do Asfalto, que conta com grande participação da comunidade. E a Festa da Baleia Jubarte, a que atrai maior número de turistas e acontece na última semana de julho. É um acontecimento ecológico, pela preservação da fauna e flora, notadamente da baleia jubarte, que chegam para reproduzirem justamente em julho e ficam até novembro. São montados stands, há apresentações musicais e vídeos sobre as riquezas naturais da região.

A maioria dessas manifestações folclóricas ainda não é aproveitada para o turismo, são somente os locais que participam. Grande parte dessas tradições locais são feitas no distrito de Helvécia e talvez por isso sejam tão pouco divulgadas. No entanto uma cultura rica como esta, de descendentes de negros escravos, deveria ser mais aproveitada para o ecoturismo, sempre respeitando a vontade dessas populações.

\section{Manifestações artísticas}

$\mathrm{O}$ artesanato local pode ser mais incentivado. O que mais se vende para os turistas são souvenires que vêm de outros locais. O principal artesanato local hoje é a fabricação de móveis rústicos de madeira. No entanto, segundo entrevista com o Sr. Samuel, presidente da Associação dos artesãos de Nova Viçosa, a venda deste tipo de produto para o turista é muito difícil, pelo tamanho das peças. Eles vendem mais em feiras fora da cidade. A associação dos artesãos local é pouco ativa em relação ao turismo. Existe ainda um grupo de capoeira e grupos carnavalescos como o Bloco da Lama e o Bloco dos Índios. 
Em termos de manifestações artísticas, se destaca o ecologista e artista plástico Franz Krajcberg, de renome internacional, que já virou personalidade de Nova Viçosa e escolheu a cidade para abrigo. Ele trabalha com materiais da natureza, tendo raízes, folhas e troncos como elementos de sua obra. É dele a casa na árvore. Em outubro de 2003, o artista está pretendendo inaugurar um museu que fica dentro de suas terras, o sítio Natura. Este museu, dependendo de como for trabalhado, pode se tornar um local de integração cultural e educação ambiental.

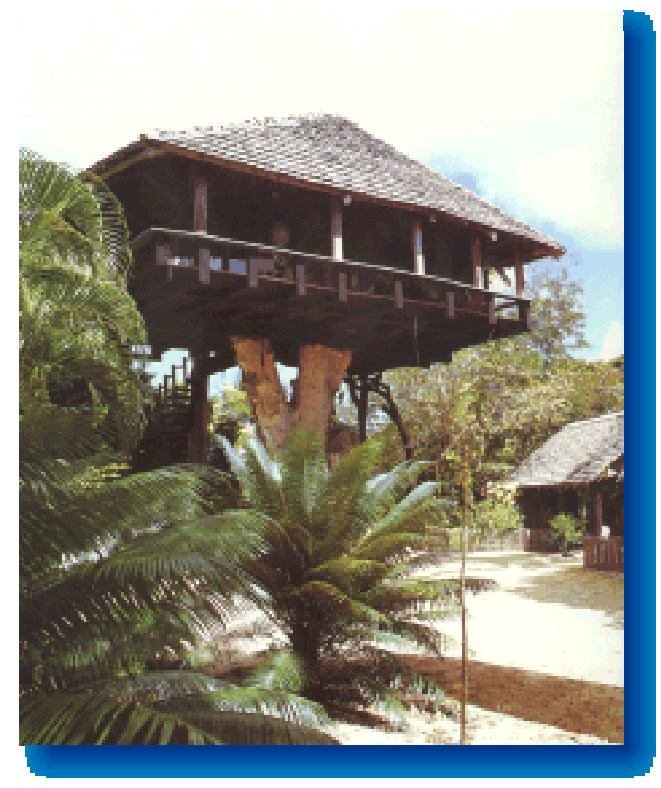

Figura 10 - Casa na árvore

\subsection{ATORES SOCIAIS}

Falar em atores sociais é falar da própria atividade turística, seu sucesso e seu fracasso estão diretamente relacionados com as ações que os atores sociais do turismo tomam ao longo do desenvolvimento do turismo em uma região. Para que o turismo tenha mais chance de dar certo é importante que estes atores ajam de forma integrada, buscando objetivos comuns. É claro que muitas vezes os diversos atores vão ter opiniões divergentes, mas faz-se necessário que cheguem a um meio termo, ou que a vontade da maioria prevaleça.

Como já foi mostrado neste trabalho, o turismo depende de vários fatores para se desenvolver de forma responsável e, por isso mesmo envolve muitas pessoas direta ou 
indiretamente. Em Nova Viçosa, pelo que se pode observar, não há integração entre os atores sociais. O turismo se desenvolve mais de forma espontânea, agora é que estão começando a tentar se organizar.

Os principais atores do turismo são o governo, a iniciativa privada, a comunidade receptora, Organizações Não Governamentais (ONGs) e o próprio turista. A participação da prefeitura se dá através da Secretaria de Turismo e Meio Ambiente. O município faz parte do Programa Nacional de Municipalização do Turismo (PNMT) da EMBRATUR. Participou da $3^{\text {a }}$ fase do PNMT em Prado e agora vai entrar na fase das oficinas do PNMT. Como já mencionado, o município possui um Conselho Municipal de Turismo, que parece não ser tão atuante, pois se reúne poucas vezes no ano.

O Fundo Municipal de Turismo ainda não foi criado, mas em entrevista a secretaria de turismo Vanda Luzia, disse que pretendia cria-lo ainda no primeiro semestre deste ano. Ainda assim, ela estava receosa, pois achava que alguns empresários do turismo não iriam gostar de ter que contribuir financeiramente com o fundo.

A maior dificuldade na área governamental é que o município ainda é muito dependente das verbas do Estado e da União. A boa notícia é que o Estado da Bahia tem dado prioridade para o turismo. São eles que pagam os cursos feitos pelo SEBRAE e outras empresas. Além disso, o PRODETUR NE -II vai fornecer verba para os municípios da Costa das Baleias para melhoria de infra-estrutura e capacitação profissional.

As principais ações feitas pela Secretaria de Turismo e Meio Ambiente no ano de 2002 até fevereiro de 2003 foram:

- Programa Natureza Viva, onde foram revitalizados alguns pontos turísticos da cidade, através de limpeza da Orla e do Canal do Peruípe;

- Encontro e cadastro dos trabalhadores ambulantes com parceria do SEBRAE, dando curso de higiene e qualidade no atendimento;

- Colocação de postos de informação ao turista nos picos sazonais e em alta temporada; 
- Projeto de sinalização turística e de trânsito feito pela secretaria de estado em convênio com o DETRAN - BA e a Prefeitura de Nova Viçosa.

Além disso, Nova Viçosa sediou as reuniões do PRODETUR NE - II referentes aos municípios de Nova Viçosa/Mucuri, onde foi entregue ao município uma cópia da síntese do diagnóstico feito por consultores da FGV para o PRODETUR NE-II. Sediou também a $1^{\text {a }}$ reunião dos atores da $4^{\mathrm{a}}$ região da MESOJEQUIMUCURI ${ }^{13}$ (Mesoregião do Jequitinhonha Mucuri), que visava debater e consolidar as propostas do estatuto para criação da Agência de Desenvolvimento da Mesoregião e realizar um diagnóstico coletivo da mesma. Desta Mesoregião participam vários municípios dos estados da Bahia, Minas e Espírito Santo.

Estes encontros são importantes para que Nova Viçosa se integre com as regiões próximas, integrando também os três estados (Bahia, Espírito Santo e Minas Gerais), buscando soluções para os problemas da região. Os primeiros passos estão sendo dados nessa direção, mas pelo que pôde ser observado, apesar de Nova Viçosa ter sediado o encontro, não houve uma participação mais ativa dos atores locais. Estavam presentes algumas pessoas locais ligadas ao turismo e meio ambiente, mas sendo esta uma reunião para criação de uma agência de desenvolvimento, outras pessoas de outras áreas como saúde, educação, agricultura, dentre outras, também deveriam estar presentes.

Os projetos futuros, segundo entrevista com a secretária de turismo Vanda Luzia, são de lançar o programa Natureza Viva na escola, fazendo palestras e encontros com os pais dos alunos, falando sobre o problema do lixo e da importância da atividade turística. Prevê-se a realização de alguns cursos de capacitação profissional para o turismo, implantação do projeto de sinalização turística e de trânsito, e também um projeto para o tombamento e restauração do centro histórico da cidade, ainda sem previsão de ser efetuado. Na área de marketing, a Secretaria de Turismo vai participar divulgando Nova Viçosa em dois eventos em 2003, o encontro da Associação Brasileira das Agências de Viagens (ABAV) que será de 22 a 26/10

\footnotetext{
${ }^{13}$ Esta reunião se deu nos dias 21 e 22 de fevereiro de 2003, período em que a autora estava fazendo a pesquisa de campo.
} 
no Rio de Janeiro e um workshop da Operbrás (Operadora de Belo Horizonte) em Belo Horizonte.

A secretária de turismo Vanda Luzia relatou em entrevista que, no ano passado a única promoção de Nova Viçosa foi em um workshop feito em Governador Valadares, no Shopping Valadares através de um programa feito pela Bahiatursa chamado Bahia nas Gerais onde empresários de turismo e as prefeituras/secretarias de turismo da Costa das Baleias tiveram a oportunidade de se promoverem.

Infelizmente, segundo a secretária, ela foi a única representante de Nova Viçosa. Ela divulgou a cidade como um todo, mas não podia fechar negócios, pois não havia empresários de Nova Viçosa. Os outros municípios da Costa das Baleias estavam presentes e seus empresários tiveram a oportunidade de vender o seu destino diretamente ao consumidor. Isso mostra como a integração e a participação dos atores locais ainda é fraca em Nova Viçosa.

Os empresários de turismo de Nova Viçosa estão começando a se organizar melhor agora. Em setembro de 2002, foi criado um grupo gestor de um movimento chamado Próturismo. Este grupo é constituído de apenas sete empresários locais, e fez um diagnóstico turístico juntamente com o SEBRAE. As principais ações apontadas para 2003 foram a capacitação profissional (diversos cursos tanto para os empresários como para os profissionais operacionais) e a elaboração de um plano de marketing que estava previsto para dezembro de 2002 e não realizado até o momento.

O grupo realizou duas ações por enquanto, juntamente com a Prefeitura /Secretaria de Turismo e Meio Ambiente. Uma delas foi a limpeza do Porto de Nova Viçosa e a outra foi a realização de um curso de gestão empresarial pelo SEBRAE. O grupo, segundo entrevista com uma das integrantes, dona da Atobá turismo, se reúne toda terça-feira, mas na época de alta temporada as reuniões ficam suspensas.

Existem várias associações em Nova Viçosa, dentre as quais as que estão mais diretamente relacionadas com o turismo são a Associação dos Cabaneiros de Nova Viçosa 
(ASCANOVI), a Associação dos hotéis, pousadas, campings, condomínios de Nova Viçosa (ASHONOVI) e a Associação Comercial de Nova Viçosa. Dentre estas, a única que foi possível fazer entrevista foi com a presidente da ASHONOVI, Lucenildes Maria Fernandes.

Pelo que foi dito na entrevista, esta associação tem 22 associados e se reúnem de dois em dois meses ou quando tem algum evento para organizar. Na alta temporada as reuniões também estavam suspensas. Destes associados, quatro pessoas participam também do grupo gestor pró-turismo e a presidente da associação também faz parte do Conselho Municipal de Turismo. Dentre as realizações da associação estão a confecção e a colocação de três outdoors de sinalização na BR 101, um no sentido de quem chega de Vitória, outro no sentido de quem vem de Salvador e também na BR-418, no sentido de quem vem de Nanuque. A confecção de um CD e DVD apresentando Nova Viçosa e as Pousadas.

As ações previstas para este ano são a participação no plano plurianual da Prefeitura de Nova Viçosa, nos projetos do governo do estado para desenvolver a infra-estrutura local e na criação da Agência de Desenvolvimento da Mesoregião do Jequimucuri. Além participar de feiras e congressos promovendo Nova Viçosa, realização de um campeonato de Taekendo e outro de pesca esportiva em junho e ajudar na organização da Festa da Baleia em julho.

Outras associações que também devem participar das decisões no desenvolvimento do turismo local são a Associação de Pesca Aqüicultura Noviçosence (PESCANOVA), e a Colônia dos Pescadores já que alguns pescadores também fazem passeios a Barra Velha, por exemplo, em barcos de pesca o que não é permitido pela capitania dos portos. A associação devia se organizar melhor para poder regularizar a situação, comprando um barco em comum para fazer passeios.

Outra associação que deveria ter uma atuação mais forte é a de artesãos, incentivando o artesanato local, dando cursos para que o artesanato local seja vendido diretamente ao turista, o que quase não ocorre hoje, segundo entrevista com o presidente da associação. A integração das diversas associações fortaleceria o envolvimento da comunidade local entorno da atividade turística, assim a comunidade poderia ter mais força e ajudar a tomar as decisões que 
vão mexer diretamente com a vida e o trabalho delas. Que tipo de turismo a comunidade quer desenvolver? O que precisa ser melhorado? Quais são as prioridades?

Associações já existentes como Associação Clube de Mães Madre Joana de Jesus, Associação Comunitária Amigos de Nova Viçosa, Associação Máster de Nova Viçosa, Clube da Melhor Idade, Rotary Club de Nova Viçosa, e as outras já citadas mais ligadas ao turismo, poderiam se integrar mais para definir as questões acima e muitas outras que as afetam direta ou indiretamente.

A comunidade local deve participar de todo o processo, deve entender a importância do turismo para o local, e compreender os impactos que ele causa. Para que o desenvolvimento do turismo seja conduzido de forma sustentável, a população local deve ser ouvida e consultada, sempre participando efetivamente do planejamento turístico local.

O turismo pode ajudar a preservar não só os recursos naturais existentes na região, mas principalmente pode resgatar costumes, valorizar a cultura de um povo, sua história, suas artes, seu folclore. Enfim, pode resgatar e valorizar as raízes e peculiaridades de uma população, contribuindo bastante para a melhoria da qualidade de vida da mesma.

Como se pode observar no capítulo de turismo receptivo, para o turista, a hospitalidade da comunidade de Nova Viçosa foi um dos pontos altos da experiência turística. Isto é sinal que a maioria da população local aprova o desenvolvimento do turismo. No entanto, segundo a mesma pesquisa o tipo de turista que visita a cidade gasta pouco e utiliza, na maioria das vezes, segunda residência ou fica em casa de parentes e amigos.

É preciso que a comunidade, juntamente com a iniciativa privada e o governo discuta se é este o tipo de turista que querem receber. Se não for, é preciso que se faça um plano de marketing para atingir outro tipo de turista e mudar essas características com o tempo. Nova Viçosa tem grande potencial para o ecoturismo, mas por enquanto, esse tipo de turismo é pouco explorado. 


\section{DESAFIOS E RECOMENDAÇÕES}

O principal desafio da cidade de Nova Viçosa hoje é conseguir uma maior participação e integração dos atores envolvidos na atividade turística. Esta participação está começando acontecer, mas hoje, somente um grupo muito pequeno participa mais efetivamente. Assim mesmo as freqüências de suas reuniões são muito espaçadas, o que pode desestimular e dificultar a obtenção de resultados mais efetivos.

Para que o turismo se desenvolva de forma organizada e responsável é necessário maior comprometimento das partes envolvidas. É preciso decidir aonde se quer chegar e em quanto tempo, dentro dos recursos disponíveis. É importante seguir objetivos comuns para que se possa reunir forças e alcançá-los. Definição de ações e prazos também são muito importante, sem isso os objetivos dificilmente serão cumpridos.

O único modo de envolver uma comunidade é realizando várias reuniões convidando a comunidade como um todo a participar (às vezes é preciso ser insistente para conseguir a participação local), estas reuniões têm que ser objetivas e dinâmicas para que as pessoas não fiquem desestimuladas. Existem alguns cursos específicos do SEBRAE onde são feitas dinâmicas para mostrar a importância da participação de todos nas decisões do município, que falam sobre cidadania.

Em outros cursos a comunidade realiza um diagnóstico participativo, fazendo com que o cidadão se envolva com os problemas de sua comunidade e busque soluções para estes problemas ou ao menos saiba decidir o que deve ser resolvido primeiro. A importância disso é que a prefeitura passa a ser mais cobrada, fiscalizada. Com um governo participativo a comunidade se torna uma parceira do governo, pois estará sabendo e acompanhando as dificuldades encontradas para se resolver determinados problemas locais.

Depois de conseguir envolver mais a comunidade, o outro desafio é definir o tipo de turismo que se quer desenvolver na cidade. É verdade que a cidade possui enorme quantidade 
de recursos naturais e culturais, mas estes recursos precisam ser trabalhados e transformados em produtos turísticos ou ecoturísticos. Nova Viçosa tem potencial para desenvolver o ecoturismo, e com os recursos que o Governo Estadual e o PRODETUR NE-II vão oferecer nos próximos anos, muitos dos problemas de infra-estrutura e da falta de capacitação poderão ser minimizados.

Depois de definido o tipo de turismo a ser desenvolvido, a primeira ação deve ser elaborar um plano de marketing de Nova Viçosa, tendo como objetivo maior minimizar a forte sazonalidade que o município enfrenta hoje. Neste plano de marketing é importante que se contextualize a cidade dentro do programa de marketing estadual, que é a Costa das Baleias, no entanto, a cidade deve descobrir qual é o seu diferencial em relação aos outros municípios da Costa das Baleias, pois estes são seus principais concorrentes.

Apesar de dizer em seus folhetos de marketing que Nova Viçosa é um "Paraíso Ecológico" e de no I Guia Turístico e Cultural de Nova Viçosa o Sr. Prefeito afirmar que “Aqui praticamos o TURISMO SUSTENTÁVEL, procurando preservar a nossa orla privilegiada, com seus manguezais e restingas ricos em biodiversidade e recantos verdadeiramente paradisíacos, além de resgatar as suas raízes histórico-culturais", na realidade o turismo que se desenvolve hoje em Nova Viçosa não é sustentável.

É preciso ter mais cuidado com este tipo de afirmação. A sustentabilidade tem sido bastante discutida, e é muito difícil de ser alcançada, pois envolvem diversos fatores, ambientais, econômicos e sociais. Para haver turismo responsável, é imprescindível que haja um controle, uma participação e uma organização maior no desenvolvimento da atividade turística. E hoje, pelo que foi observado em campo e através de dados de fontes secundárias, a atividade turística cresce de forma espontânea, sem direcionamento e controle de nenhum tipo.

A principal proposta deste trabalho é que Nova Viçosa aproveite seu potencial de recursos naturais e culturais ímpares e desenvolva o ecoturismo. O ecoturismo é mais conhecido por sua preocupação com a conservação do meio ambiente, aspecto importante, porém não o único. $\mathrm{O}$ verdadeiro ecoturista se preocupa com os impactos que está causando e 
adota uma postura de mínimo impacto tanto ambiental como social. Além disso, ele quer aprender mais sobre o destino que está visitando e muitas vezes quer também contribuir para a conservação do ecossistema que está visitando.

O ecoturismo visa promover o bem estar das populações envolvidas, dinamizando a economia local e gerando novas alternativas de emprego e renda. Outros setores da economia como agricultura sustentável, artesanato, comércio local, são incentivados pelo ecoturismo.

Outra diferença entre o ecoturismo e o turismo convencional é que as operadoras e agências envolvidas diretamente com os passeios ecoturísticos têm que ter uma postura conservacionista, tendo também que preparar seus visitantes visando minimizar os possíveis impactos negativos, trabalhar com um grupo de turistas não muito grande, contratar mão-deobra local e treina-la com vistas à conservação ambiental, além de contribuir para a conservação daquele ambiente e respeitar os costumes do local.

\section{Propostas}

O primeiro passo é levar o Plano Diretor Urbano para aprovação na Câmara de Vereadores o mais rapidamente possível. Depois disso já começar a fazer a complementação deste, para que no prazo máximo de três anos, o Plano Diretor Municipal fique pronto. O motivo é que grande parte dos atrativos ecoturísticos se encontram em área rural. É importante também realizar o plano de manejo do Parque Ecológico Municipal, através de parcerias com universidades próximas ao município.

Outra responsabilidade do governo municipal é melhorar a infra-estrutura. A infraestrutura de acesso do município é muito boa, mas a construção de um terminal rodoviário na cidade de Nova Viçosa é necessária para o maior conforto do turista.

Buscar maior integração com os municípios da Costa das Baleias, principalmente a cidade vizinha Mucuri, para resolução de problemas comuns como saneamento básico e tratamento dos resíduos sólidos. Poderiam ser construídas uma estação de tratamento de 
esgoto e um aterro sanitário em comum para as duas cidades. O recurso poderia vir do Governo do Estado e do PRODETUR NE-II.

Ao mesmo tempo, deveriam ser realizadas campanhas de esclarecimento para a implantação da coleta seletiva do lixo no município de Nova Viçosa. Esta deve ser feita por etapas, iniciando pelo governo municipal, indústria, comércio e serviços. Depois passando para as áreas residenciais urbanas e por último nas áreas rurais.

Poderia ser criada lei municipal que tratasse da questão do lixo, onde todos os estabelecimentos e casas, principalmente os que se situam a beira mar, no centro histórico ou em local de grande atratividade turística teriam que conservar a sua frente. A punição seria através de multas que seriam revertidas para a educação ambiental ou compra de lixeiras e outros equipamentos para limpeza pública.

Outro trabalho que poderia ser feito dentro da educação ambiental com a comunidade é o de oficinas de reciclagem de materiais como lacre de refrigerantes, garrafas pet e outros para realização de artesanato, como bolsas e estojos, por exemplo. Além dessas, outras ações na área da educação ambiental poderiam ser feitas como competições entre as escolas ou até mesmo intermunicipais de desenho, música, redação, gincanas que tenham como tema principal o meio ambiente ou motivos da fauna e flora local. Além de visitas dos alunos da rede municipal e estadual aos atrativos naturais e culturais do município.

A educação ambiental ao turista poderia ser através de estabelecimento de regras de conduta e nas trilhas interpretativas. Poderia se promover a criação de um centro de visitantes na Praça da Baleia, onde seriam dadas informações sobre a cidade e os atrativos existentes. Também seria feito um trabalho de educação ambiental com as pessoas que fossem as ilhas de Coroa Vermelha, Barra Velha, aos recifes de Sebastião Gomes, e aos passeios de Caravelas e Abrolhos (falaria não só dos locais citados, mas também de outros ecossistemas da região como o manguezal e a floresta de Mata-Atlântica). No centro de visitantes poderiam ser vendidos materiais (camisetas, bonés, e outros) com motivos da fauna e flora locais, com o dinheiro arrecadado sendo usado para mante-lo. 
Outras campanhas também poderiam ser feitas principalmente com as empresas diretamente ligadas ao turismo, como a de redução do consumo de energia e de desperdício de água, buscando mostrar ao consumidor dos serviços turísticos que ele também pode contribuir para a conservação ambiental local. Normalmente os ecoturistas colaboram e até dão preferência às empresas que trabalham visando à conservação.

Outra alternativa seria incentivar a produção local, principalmente a agricultura familiar, criação de vacas leiteiras e fabricação de queijos, fabricação de doces caseiros, cocada, fruticultura, pesca artesanal, artesanato local para abastecimento dos meios de hospedagem, restaurantes, quiosques e outros serviços oferecidos ao turista.

Outra proposta é a de implantar o projeto de sinalização turística e de trânsito e de colocar em caráter emergencial uma placa localizando a Secretaria de Turismo, onde funciona o único posto permanente de informação ao turista. Ainda quanto à circulação interna da cidade, incentivar o uso de bicicleta por parte dos turistas (a cidade possui local que aluga bicicletas) visto que a população local utiliza bastante a bicicleta como meio de locomoção e tendo em vista que a cidade é relativamente pequena.

Aumentar o efetivo policial em época de picos sazonais como Carnaval e Ano Novo. Principalmente para o combate às drogas e prostituição infanto-juvenil. E uma vez que não existe corpo de bombeiros no município, deve-se treinar uma equipe de busca e salvamento para atender ao município, pois com o desenvolvimento do ecoturismo na região este serviço será mais necessário. Outro serviço que deve ser ampliado é o do Banco do Brasil, deveria aumentar o número de caixas eletrônicos (só tem um na cidade) em alta temporada e se possível no futuro reativar a agência do Banco do Brasil que foi transferida para Posto da Mata (distrito de Nova Viçosa).

Aumentar o número de reuniões do Conselho Municipal de Turismo para no mínimo uma vez por mês, o ideal é que fosse quinzenalmente, para que as ações tenham uma maior continuidade. Criação do Fundo Municipal de Turismo, onde poderia ser criada uma lei 
municipal em que fosse cobrado dos turistas uma taxa simbólica $(\mathrm{R} \$ 1,00)$ na diária dos hotéis e passeios as ilhas por exemplo. Este dinheiro iria para o Fundo Municipal do Turismo, o dinheiro da taxa por diária poderia servir para a divulgação do município, fazendo com que o fluxo aumentasse e conseqüentemente as divisas também. Já as taxas cobradas por passeios às ilhas de Coroa Vermelha e Barra Velha, poderiam ajudar na manutenção e conservação desses locais.

Aproveitar os investimentos que o PRODETUR NE-II e o Governo do Estado vão fazer na área de capacitação e, juntamente com o Governo Municipal, associações ligadas ao turismo, empresários do turismo e o Grupo Gestor Pró-turismo, realizar cursos que busquem ajudar a integração dos atores locais e regionais bem como a maior participação da comunidade nas decisões do município. Cursos como o Liderança e o Líder Cidadão do SEBRAE, por exemplo. Elaboração de uma Política Pública Municipal para o Ecoturismo e futuramente de um Plano Municipal para o Desenvolvimento do Ecoturismo de forma participativa

Solicitação também de cursos para condutores de ecoturismo e futuramente para formação de guias locais, bem como outros na área de hotelaria, alimentos e bebidas. Tanto na área de gestão empresarial como na de operacionalização dos serviços. É importante que nestes cursos sempre se enfoque dois fatores principais, o primeiro é conservacionista, envolvendo os empresários e os funcionários com a questão ambiental, mostrando como eles podem minimizar os impactos negativos do turismo. E o segundo é prezar sempre pela qualidade dos serviços prestados.

Uma das principais propostas é a elaboração de roteiros ecoturísticos e históricoculturais. As duas agências locais têm que elaborar estes roteiros dentro dos preceitos do ecoturismo. Ou seja, visando mínimo impacto, primando pela educação ambiental e históricocultural dos turistas, reaproveitando trilhas existentes e elaborando novas com a ajuda de um profissional especializado em trilhas interpretativas, incentivando a formação de condutores e guias locais. Agregando valor aos recursos existentes. 
Primeiramente, é preciso melhorar os roteiros já existentes. Os passeios às ilhas de Barra Velha e Coroa Vermelha devem ter um condutor acompanhando, falando sobre o local visitado, de sua fauna e flora. Em Barra Velha, como o local é uma vila de pescadores, os condutores devem ser da ilha. Condução através de uma trilha já existente pela praia de aproximadamente $4 \mathrm{~km}$ até o Pontal do Catoeiro. Poderia ser montado um quiosque de recepção ao turista onde esses condutores recepcionariam o visitante e, onde seria exposto o artesanato local, os doces caseiros (feitos, por exemplo, pelas mulheres da ilha), venda de água de coco, protetor solar e repelente.

No caso de Coroa Vermelha, os condutores já sairiam junto com o grupo de Nova Viçosa. Estas agências podem e devem realizar parcerias com operadoras de ecoturismo em outros estados. Algumas sugestões de roteiros que podem ser trabalhados são:

- Roteiros de mergulho, que envolveria Abrolhos, Coroa Vermelha e os Recifes de Sebastião Gomes. Poderiam ser feitas divulgação em sites e revistas especializadas em mergulho e feitos convênios com casas de mergulho, em um primeiro momento dos estados mais próximos como Espírito Santo, Minas Gerais e a própria Bahia. Depois em capitais como São Paulo, Rio de Janeiro, Brasília e Goiânia;

- Roteiros para pesca esportiva, que poderiam ser em Coroa Vermelha e outros bons locais de pesca próximos à Nova Viçosa. Estes roteiros inclusive poderiam ser operacionalizados pelos pescadores locais, as associações ligadas à pesca local poderiam ajudar na elaboração do mesmo. A divulgação poderia ser nos sites de pesca esportiva e em revistas especializadas;

- Roteiro histórico-cultural, passeio de um dia visitando a cidade histórica com acompanhamento de guia, bem como visitação ao distrito de Helvécia falando sobre sua origem e cultura;

- Roteiros pela Ilha do Cassumba, passeio de um dia com guia visitando o local que reúne diversos ecossistemas como manguezal, praia, mata atlântica. O acesso é fluvial. 
- Roteiros pelos remanescentes de Mata Atlântica, estes roteiros poderiam ser abertos no Parque Ecológico Municipal ou em propriedades particulares, onde se poderia observar a flora e a fauna locais. Com o tempo pode-se também começar a pensar em roteiros para avistar pássaros, visto que em Nova Viçosa existem pássaros raros e migratórios.

Depois de melhorarem os roteiros existentes e elaborarem alguns novos que devem ser implementados com o tempo, é preciso que o município faça um plano de marketing com a participação dos atores sociais. Este plano deve visar em um primeiro momento quebrar a sazonalidade existente hoje e claro, mudar o tipo de turismo que é desenvolvido em Nova Viçosa.

Uma estratégia que pode ser usada para quebrar a sazonalidade e ao mesmo tempo mudar o perfil do visitante é a de elaboração de novos eventos e uma maior divulgação dos já existentes, principalmente nas cidades e estados próximos a Nova Viçosa. Eventos como o da Festa da Baleia e a Festa de São Pedro devem ser fortalecidos e mais divulgados. Poderiam ser criadas ainda, as semanas de pesca esportivas e o festival do camarão já que no município tem pesca do camarão.

Outra estratégia de marketing pode ser a de oferecer nas cidades próximas pacotes promocionais de fim de semana, onde a pessoa pode participar de pelo menos um roteiro ecoturístico. Realizar parcerias com as faculdades e universidades para realização de estudos e projetos na região e divulgar também os pacotes aos estudante dando descontos especiais, principalmente nos cursos relacionados a área ambiental.

Outras idéias devem ser ouvidas, principalmente as da comunidade que conhecem melhor suas festas e suas potencialidades. A integração com os outros municípios da Costa das Baleias é importante, os municípios podem divulgar juntos a Costa em feiras, congressos e workshops de turismo. 
Além disso, é importante manter a página de turismo oficial do Município sempre atualizada, facilitando o contato do turista com os prestadores de serviços locais:

- Criando espaços para que os turistas deixem sua opinião sobre a cidade;

- Divulgando e promovendo os eventos locais;

- Disponibilizado ao visitante informações de comportamento em áreas naturais frágeis, dos projetos ambientais desenvolvidos na cidade, dentre outros. 


\title{
CONCLUSÃo
}

\begin{abstract}
Este projeto visou tão somente identificar os principais desafios para o desenvolvimento do turismo de uma forma mais responsável e propor novos rumos no desenvolvimento do turismo local. A análise dos dados obtidos neste projeto permite concluir que o município de Nova Viçosa não vem desenvolvendo o turismo de forma sustentável. E por isso, a principal sugestão foi a de desenvolver o ecoturismo na região, tendo em vista a riqueza de seus recursos naturais e culturais.
\end{abstract}

O município, pelo pouco que se pôde verificar, não tem condições de fazer no momento um planejamento ecoturístico adequado. Faltam estudos e legislações básicos para que o turismo se desenvolva de forma a não degradar a natureza e cultura local. O plano diretor urbano vai ajudar bastante, mas é preciso complementa-lo o mais rapidamente possível, pois a maioria das áreas que serão utilizadas para o ecoturismo estão em área rural.

Um dos problemas mais sérios que o município enfrenta e que trás com ele vários outros, é o problema da sazonalidade. O município recebe um grande número de pessoas em um curto espaço de tempo e não está preparado para isso. Alguns exemplos são o problema que a cidade de Nova Viçosa vêm enfrentando com o lixo e com o aumento de preço dos produtos na alta temporada.

Para que este problema maior seja minimizado, é necessário que seja feito um plano de marketing para a cidade, visando buscar novos mercados, fazendo assim, com que os picos sazonais diminuam. Este plano, conforme já foi mencionado anteriormente, poderia ser subsidiado parcialmente pelo Fundo Municipal do Turismo, através de cobrança de uma taxa de turismo.

Sendo assim, para que a atividade turística do município desenvolva-se da melhor maneira possível, é importante que a iniciativa privada, o Governo Municipal e a comunidade receptora unam forças e através do Conselho Municipal do Turismo discutam quais ações 
devem ser tomadas para que haja um equilíbrio entre os interesses econômicos, sociais e a preservação da natureza, da história e da cultura local, mantendo com isso, a sustentabilidade da atividade turística da cidade de Nova Viçosa. 


\section{BIBLIOGRAFIA}

- ARACRUZ CELUlOSE S. A., RIMA - Relatório de Impacto Ambiental Empreendimento Florestal no Extremo Sul da Bahia, Relatório Técnico - RT 040/00, Agosto/2000.

- BARRETO, Margarita. Manual de Iniciação ao Estudo do Turismo. Campinas, SP: Papirus, 1995.

- BAHIATURSA. Pesquisa de turismo receptivo dos municípios de Mucuri/ Nova Viçosa. Salvador - BA: BAHIATURSA, 2000.

- DENCKER, Ada de Freitas Maneti. Métodos e técnicas de pesquisa em turismo. $2^{\mathrm{a}}$ edição. São Paulo, SP: Futura, 1998.

- FGV/HVS International. PRODETUR NE-II Síntese do Diagnóstico Costa das Baleias - reunião de Nova Viçosa. São Paulo Office. Outubro/2002.

- NEVES, Maialú Ferreira. Análise da Atividade Turística de Nova Viçosa - BA e Sugestões para um Desenvolvimento Turístico Sustentável. Dissertação para obtenção do título de graduação em Turismo. Departamento de Turismo - União Pioneira de Integração Social, 2000. 75 p.

- SEBRAE. Diagnóstico Turístico de Nova Viçosa. Setembro/2002.

- . Proposta para o Turismo Sustentável de Nova Viçosa - Resultados Efetivos. Setembro/2002.

Sites consultados na Internet:

$<$ www.embratur.com.br/temas $>$ acesso em: 23 de maio de 2003.

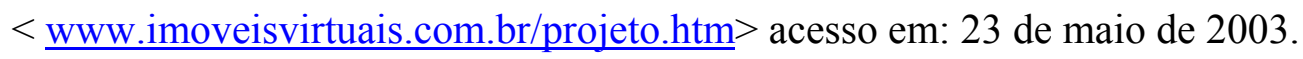

$<$ www.novavicosa.com.br $>$ acesso em: 23 de maio de 2003.

$<$ www.abrolhos.com.br $>$ acesso em: 23 de maio de 2003.

$<$ www.ibge.gov.br $>$ acesso em: 23 de maio de 2003.

$<$ www.sei.ba.com.br $>$ acesso em: 23 de maio de 2003. 